\title{
Experimental Studies of Nanofluid Thermal Conductivity Enhancement and Applications: A Review*
}

\author{
Mohamed M. Tawfik ${ }^{\mathrm{a}, \mathrm{b}, * *}$ \\ a Precision Engineering Institute (Global CSP Laboratory), School of Aerospace, Transport and Manufacturing, Cranfield University, MK43 0AL, UK \\ b Mechanical Power Engineering Department, Faculty of Engineering, Mansoura University, 35516, Egypt \\ * This is a preprint form. The final published form is available online at: $\underline{\text { http://dx.doi.org/10.1016/j.rser.2016.11.111 }}$ \\ ** Corresponding Author / E-mail: m.m.tawfik@cranfield.ac.uk, m tawfik@mans.edu.eg, TEL: +44-07774 872759
}

KEYWORDS: Nanofluids, conduction, measurement, enhancement, applications

\begin{abstract}
In many applications, there is a critical need for enhancing the poor thermal conductivity of conventional fluids in order to develop efficient heat transfer fluids. This requirement can be met through dispersing nanometric particles in a given base fluid such as water, ethylene glycol, oil or air. The resulting nanofluids enhanced thermal conductivity of the base fluids. In order to evaluate this enhancement, nanofluid thermal conductivity is required to be measured. Several methods and techniques are covered in the present contribution. In addition, enhancements recorded experimentally are reviewed and summarized. Different parameters affecting on such enhancement are covered, including: nanoparticle concentration, size, shape and thermal conductivity. In addition, base fluid type, nanofluid bulk temperature and dispersion techniques are also covered parameters. However, nanofluids have the potential to contribute in several practical applications including solar thermal, transportation, electronic cooling, medical, detergency and military applications. In the present work, a brief overview of evolution in the use of nanofluids in some applications has been presented. According to this contribution, there is a critical need for further fundamental and applications of nanofluids studies in order to understand the physical mechanisms of using nanofluids as well as explore different aspects of applications of nanofluids.
\end{abstract}

\section{Nomenclature \\ $k_{b f}=$ Base fluid thermal conductivity, $\mathrm{W} / \mathrm{m} . \mathrm{K}$ \\ $k_{n f}=$ nanofluid thermal conductivity, $\mathrm{W} / \mathrm{m} . \mathrm{K}$ \\ $q=$ heat flux, $\mathrm{W} / \mathrm{m}^{2}$ \\ $r=$ radial coordinate, $\mathrm{m}$ \\ $T=$ temperature, $\mathrm{K}$ \\ $t=$ time, $\mathrm{s}$ \\ $\alpha_{n f}=$ nanofluid thermal diffusivity, $\mathrm{m}^{2} / \mathrm{s}$ \\ $\omega=$ electric current frequency, $\mathrm{Hz}$}

\section{Abbreviations}

$$
\begin{aligned}
& \mathrm{BG}=\text { BioGlycol } \\
& \mathrm{CNF}=\text { Carbon nanofiber } \\
& \mathrm{CTAB}=\text { Hexadecyltrimethylammonium bromide } \\
& \mathrm{DE}=\text { Decene } \\
& \mathrm{DI}=\text { Deionized water } \\
& \text { DWCNT }=\text { Double-walled carbon nanotubes } \\
& \text { DO }=\text { Diathermic oil } \\
& \mathrm{EG}=\text { Ethylene glycol } \\
& \mathrm{EO}=\text { Engine oil } \\
& \mathrm{HTF}=\text { High-temperature heat transfer fluid } \\
& \mathrm{HTO}=\text { Heat transfer oil } \\
& \mathrm{MEG}=\text { Mono ethylene glycol } \\
& \mathrm{MO}=\text { Mineral Oil } \\
& \text { MWCNT }=\text { Multi-wall carbon nanotube } \\
& \mathrm{NSAQ}=\text { Nanosperse AQ } \\
& \mathrm{OAK}^{+}=\text {Potassium oleate } \\
& \mathrm{PO}=\text { Pump oil } \\
& \text { TH66 }=\text { Therminol } 66
\end{aligned}
$$

\section{Introduction}

Heat transfer is one of the most important processes in many industrial and consumer products. For more than a century, scientists and engineers have made great efforts to enhance the inherently poor thermal conductivity of conventional fluids [1,2]. In 1873, Maxwell [3] proposed an idea of using metallic particles to enhance the electrical or thermal conductivity of matrix materials. He presented a theory for effective conductivity of slurries, by dispersing millimeter- or micrometer-sized particles (typically have size between 0.1 and $100 \mu \mathrm{m}$ [4]) in liquids. However, major problems such as sedimentation, erosion, and high pressure drop prevented the usual micro-particle slurries to be used as heat transfer fluids. Nanofluids, which is a dilute suspension of nanometer-size particles or fibers (typically less than $100 \mathrm{~nm}$ ) dispersed in a fluid such as water, oil, and ethylene glycol (EG) [5], have emerged as a potential candidate for the design of heat transfer fluids [6]. According to their potential applications in the heat transfer field, nanofluids have been a subject of intensive investigation [7-12].

According to the definition of micro- and nano-particles size, nanoparticles have surface/volume ratio 1000 times larger than that of microparticles [13]. This in turn, allows improving thermal properties of nanofluids rather than microparticles-colloidal suspensions, since heat transfer occurs on the surface of the particle [14]. Compared with microparticles, nanoparticles stay suspended much longer in base fluids, with very little settling under static conditions, unlike micron-sized suspensions [15]. However, strong van der Waals interactions generate an aggregation tendency between nanoparticles [16]. Therefore, different techniques are utilized 
to minimize long-term particles aggregation. This process is quite critical in preparation of nanofluids as particles clustering has been reported as features increasing thermal conductivity of nanofluids [17-19]. Moreover, the number of atoms present on the surface of nanoparticles is very large, as opposed to the interior [20]. These unique properties of nanoparticles can be exploited to develop nanofluids with an unprecedented combination of the two features most highly desired for heat transfer systems: extreme stability and ultrahigh thermal conductivity. Furthermore, because the nanoparticles are so small, they may reduce erosion and clogging dramatically. Other benefits envisioned for nanofluids include decreased demand for pumping power, reduced inventory of heat transfer fluid, and significant energy savings [21].

This discovery brought about a wave of studies in this area, predominantly experimental confirmation of the huge potential of nanofluids as well as efforts to theorize the phenomenon. In this paper, various techniques used to measure thermal conductivity are covered. Then, experimental work carried on studying the thermal conductivity enhancement of nanofluids against their base fluids is reviewed. This review aims to define parameters investigated experimentally through the literature in order to find out points of agreement and conflict in the obtained results to understand the thermal behavior of nanofluids. Moreover, different applications using nanofluid is also reviewed.

\section{Thermal Conductivity Measurement Techniques}

Measuring the thermal conductivity of nanofluids can be carried out with different methods. The most common techniques for this purpose are the transient ones including: transient hot-wire method [22-37], temperature oscillation method [38,39], and 3- $\omega$ method [40-42]. Some other methods such as steady-state parallel-plate technique, micro-hot strip method, and optical beam deflection technique have also been utilized by some researchers [43-45].

\subsection{Transient Hot-Wire Method}

The transient hot-wire (THW) method is the most widely used experimental technique for measuring fluids thermal conductivity, as it is an easy and low cost method to be implemented. It is a standard transient dynamic technique based on the measurement of the temperature rise in a defined distance from a linear heat source (hot wire) embedded in the test material. A hot wire is placed in the fluid, which functions as both a heat source and a thermometer [46-48]. The ideal mathematical model of the method is based on Fourier's law, assuming the hot wire as an ideal, infinite thin and long heat source in an infinite surrounding from homogeneous and isotropic material with constant initial temperature. According to Fourier's law, when the wire is heated, fluid of higher thermal conductivity corresponds to a lower temperature rise.

The mathematical model which describes the relation between thermal conductivity $k_{\mathrm{nf}}$ and measured temperature $T$ using the THW method is explained and summarized as follows [47]. Assuming a thin, infinitely long line source dissipating heat into a fluid reservoir, the energy equation in cylindrical coordinates can be written as:

$$
\left(1 / \alpha_{n f}\right)(\partial T / \partial t)=(1 / r) \partial[r(\partial T / \partial r)] / \partial r
$$

The initial condition can be written as shown in Eq. (2):

$$
\left.T\right|_{t=0}=T_{0}
$$

while the boundary conditions are defined by Eq. (3) and Eq. (4) as follows:

$$
\lim _{r \rightarrow 0}(r(\partial T / \partial r))=(q / 2 \pi)\left(1 / k_{n f}\right)
$$

and

$$
\left.(\partial T / \partial r)\right|_{r=\infty}=0
$$

If the temperatures of the hot wire at times $t_{1}$ and $t_{2}$ are $T_{1}$ and $T_{2}$, then by neglecting higher-order terms, the thermal conductivity can be approximated as [5]:

$$
k_{n f}=(q / 4 \pi) \ln \left(t_{1} / t_{2}\right) /\left(T_{1}-T_{2}\right)
$$

Therefore, in order to determine $k_{n f}$ experimentally using THW method according to Eq. (5), a constant electric power supply is used to heat the wire with a constant heat flux, $q$, at a time step, t. A Wheatstone-bridge circuit is used to determine the temperature increase of the wire from its change in resistance. Although the THW is an easy, fast response and low cost method; its accuracy can be affected by nanoparticle interactions, sedimentation and/or aggregation, and natural convection during extended measurement times. In addition, the assumptions of an infinite wire-length and the ambient acting like a reservoir may also introduce errors [42,49].

\subsection{Temperature Oscillation Method}

This method is based on the oscillation method proposed by Roetzel et al. [50] and further developed by Czarnetzki and Roetzel [38]. Applying this method requires measuring the temperature response of the nanofluid sample when a temperature oscillation or heat flux is imposed. The measured temperature response of the sample is an indication of averaged or localized thermal conductivity in the direction of sample chamber height [51]. The experimental set up of this method is explained in details by Paul et al. [42].

\subsection{3- $\omega$ Method}

The 3- $\omega$ method is quite similar to the THW method, as it uses a radial flow of heat from a single element which acts both as the heater and the thermometer. However, the main major difference is the use of electric current frequency dependence response instead of the time dependent response which is utilized by the TWH method. When a sinusoidal current at frequency, $\omega$, passes through the metal wire, a heat wave can be generated at a frequency of $2 \omega$, which is deduced by the voltage component at frequency $3 \omega$. More details about this method are available in [42,52].

\subsection{Other Thermal Measurement Methods}

The short-hot-wire method is an improved design of the hot-wire method, in which boundary effects can be taken into account, It has been applied by [53,54]. Another modification of THW is carried out by Mintsa et al. [55], who inserted a mixer into his THW experimental devices to avoid nanoparticle aggregation/deposition in the suspensions. In order to avoid interference between the detector and heater, Ali et al. [56] 
separated them by combining the THW method with a laser beam displacement method.

\subsection{Optical Measurement Methods}

In order to improve the thermal conductivity measurement accuracy, optical measurement techniques have been proposed as non-invasive methods [57-61]. The accuracy improvement resulted from separating detector and heater from each other avoiding the unavoidable interference between them in the THW method. In addition, optical techniques provide faster measurement, within a few microseconds compared with 2 to $8 \mathrm{~s}$ of measurement using the THW method. This fast response helps in avoiding natural convection effects.

One of the proposed optical techniques is thermal-lensing (TL) method, which is applied by Rusconi et al. [57,62]. In this method, a laser-diode module was used as a heater and a photodiode was used as a thermometer to measure the temperature difference as optical signals.

The forced Rayleigh scattering (FRS) method is an extension of quasi elastic Rayleigh light scattering technique $[63,64]$. In the FRS method, two intersecting laser beams are absorbed by the sample in order to generate a spatially periodic temperature distribution. Analyzing the time dependence of the light scattered by the thermal fluctuations inside the sample was required in order to measure thermal diffusivity. The FRS was also used by many researchers to measure the thermal conductivity of nanofluids $[36,58,65]$.

Optical beam deflection was another optical technique which was used to measure thermal conductivity of nanofluids $[44,66]$. In this method, two parallel lines using a square current were used to heat the nanofluid sample. Dual photodiodes were used to capture light signals that indicate the temperature change of nanofluids.

Other optical techniques were applied by different researchers, such as the Transient Optical Grating method [59], Laser Flash method [61], Modern Light Flash technique [67]. However, there is a critical need to apply different measurement techniques for the same nanofluids in order to compare the accuracy and reproducibility of their experimental results.

\section{Experimental Studies on Conduction Heat Transfer of Nanofluids}

\subsection{Liquid-Based Nanofluids}

Liquid-based nanofluid is used to enhance thermal properties of a "liquid" base fluid. Since thermal conductivity is the most important parameter responsible for enhanced heat transfer, many experimental works have been reported on this aspect. Choi et al. [68] developed a new project to design and analyze a microchannel heat exchanger that uses liquidnitrogen as the cooling fluid which used to cool high-heat-load x-ray optical elements. They focused on the thermal conductivity of the fluid itself rather than on channel size to develop a new heat transfer fluid concept that enables heat transfer enhancement without a large pumping power increase and without cryogenic coolants. A summary of maximum measured thermal conductivity enhancement for nanofluids is given in Table 1.

According to the previous literature, there are different types of nanoparticles that were commonly used, including oxides, nanotubes, metals and carbides. These nanoparticles were dispersed in different base fluids. The number of contributions mentioned in the present work versus different nanoparticles is shown in Fig. 1, while Fig. 2 represents the number of publications per year, mentioned in this paper and concerned with experimental studies on thermal conductivity in nanofluids 
Table 1 Summary of maximum measured thermal conductivity enhancement for nanofluids

\begin{tabular}{|c|c|c|c|c|c|c|c|c|c|c|c|c|}
\hline \multirow[b]{2}{*}{ Ref. } & \multirow[b]{2}{*}{ Year } & \multirow[b]{2}{*}{$\begin{array}{l}\text { Particles Type / } \\
\text { Size (nm) }\end{array}$} & \multirow[b]{2}{*}{ Base-fluid } & \multirow[b]{2}{*}{$\begin{array}{l}\text { Loading } \\
\text { (\% vol.) }\end{array}$} & \multirow[b]{2}{*}{$\begin{array}{c}\text { Enhancement* } \\
\text { (\%) }\end{array}$} & \multicolumn{7}{|c|}{ Parameters Investigated } \\
\hline & & & & & & $\begin{array}{c}\text { Particle } \\
\text { Concentration }\end{array}$ & Particle Size & Particle Shape & $\begin{array}{l}\text { Particle Thermal } \\
\text { Conductivity }\end{array}$ & Base Fluid Type & Temperature & $\begin{array}{c}\text { Preparation } \\
\text { Technique }\end{array}$ \\
\hline \multirow[t]{3}{*}[22]{} & 1993 & $\mathrm{Al}_{2} \mathrm{O}_{3} / 13$ & Water & 4.33 & 32 & & & & & & & \\
\hline & & $\mathrm{SiO}_{2} / 12$ & & 2.3 & 1.1 & $\checkmark$ & & & & & & $\checkmark$ \\
\hline & & $\mathrm{TiO}_{2} / 27$ & & 4.35 & 11.6 & & & & & & & \\
\hline \multirow[t]{3}{*}{ [69] } & 1997 & $\mathrm{Al}_{2} \mathrm{O}_{3} / 33$ & Water & 5 & 29 & & & & & & & \\
\hline & & $\mathrm{CuO} / 36$ & & 5 & 60 & $\checkmark$ & & & & & & $\checkmark$ \\
\hline & & $\mathrm{Cu} / 35$ & HE-200 Oil & 0.052 & 44 & & & & & & & \\
\hline \multirow[t]{2}{*}{ [70] } & 1998 & $\mathrm{Al}_{2} \mathrm{O}_{3} / 13$ & Water & 4.33 & 32 & & & & & & & \\
\hline & & $\mathrm{TiO}_{2} / 27$ & & 4.35 & 11.6 & & $\checkmark$ & & $\checkmark$ & & & \\
\hline \multirow[t]{4}{*}{ [71] } & 1999 & $\mathrm{Al}_{2} \mathrm{O}_{3} / 38$ & Water & 4.3 & 10 & & & & & & & \\
\hline & & & $\mathrm{EG}$ & 5 & 18 & & & & & & & \\
\hline & & $\mathrm{CuO} / 24$ & Water & 3.41 & 12 & $\checkmark$ & $\checkmark$ & & $\checkmark$ & $\checkmark$ & & \\
\hline & & & EG & 4 & 23 & & & & & & & \\
\hline \multirow[t]{6}{*}{ [43] } & 1999 & $\mathrm{Al}_{2} \mathrm{O}_{3} / 28$ & Water & 5.5 & 16 & & & & & & & \\
\hline & & & EG & 8 & 41 & & & & & & & \\
\hline & & & EO & 7.4 & 30 & & & & & & & \\
\hline & & & PO & 7.1 & 20 & & $\checkmark$ & & & & & $\checkmark$ \\
\hline & & $\mathrm{CuO} / 23$ & Water & 9.7 & 34 & & & & & & & \\
\hline & & & EG & 14.8 & 54 & & & & & & & \\
\hline \multirow[t]{2}{*}{ [72] } & 2000 & $\mathrm{Cu} / 100$ & Water & 7.5 & 78 & & & & & & & 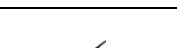 \\
\hline & & & HE-200 Oil & 7.5 & 43 & $\checkmark$ & $\checkmark$ & & & & & $\checkmark$ \\
\hline [73] & 2001 & $\mathrm{Cu} /<10$ & EG & 0.3 & 40 & $\checkmark$ & & & $\checkmark$ & & & \\
\hline [74] & 2001 & $\begin{array}{c}\text { MWCNT / } \\
\emptyset 25 \times 50,000\end{array}$ & Oil & 1 & 160 & $\checkmark$ & & $\checkmark$ & & & & \\
\hline \multirow[t]{4}{*}{ [23] } & 2002 & $\begin{array}{c}\mathrm{SiC} \\
\text { (sphere)/26 }\end{array}$ & DI & 4.2 & 15.8 & & & & & & & \\
\hline & & $\begin{array}{l}\mathrm{SiC} \text { (cylinder) / } \\
600\end{array}$ & & 4 & 22.9 & & & & & & & \\
\hline & & $\begin{array}{c}\mathrm{SiC} \\
\text { (sphere)/26 }\end{array}$ & $\mathrm{EG}$ & 3.5 & 13 & $\checkmark$ & & $\checkmark$ & & $\checkmark$ & & \\
\hline & & $\begin{array}{l}\mathrm{SiC} \text { (cylinder) / } \\
600\end{array}$ & & 4 & 23 & & & & & & & \\
\hline \multirow[t]{5}{*}[75]{} & 2002 & $\mathrm{Al}_{2} \mathrm{O}_{3} / 29$ & EG & 4 & 17 & & & & & & & \\
\hline & & $\mathrm{CeO}_{2} / 29$ & & 4 & 18 & & & & & & & \\
\hline & & $\mathrm{TiO}_{2} / 40$ & & 4 & 13 & $\checkmark$ & $\checkmark$ & & $\checkmark$ & & & $\checkmark$ \\
\hline & & $\mathrm{CuO} / 33$ & & 4 & 17 & & & & & & & \\
\hline & & $\mathrm{Fe}_{2} \mathrm{O}_{3} / 28$ & & 4 & 16 & & & & & & & \\
\hline
\end{tabular}




\begin{tabular}{|c|c|c|c|c|c|c|c|c|c|c|c|c|}
\hline \multirow{3}{*}{ Ref. } & \multirow{3}{*}{ Year } & \multirow{3}{*}{$\begin{array}{c}\text { Particles Type / } \\
\text { Size (nm) }\end{array}$} & \multirow{3}{*}{ Base-fluid } & \multirow{2}{*}{$\begin{array}{l}\text { Loading } \\
\text { (\% vol.) }\end{array}$} & \multirow{2}{*}{$\begin{array}{c}\text { Enhancement* } \\
\text { (\%) }\end{array}$} & \multicolumn{7}{|c|}{ Parameters Investigated } \\
\hline & & & & & & $\begin{array}{c}\text { Particle } \\
\text { Concentration }\end{array}$ & Particle Size & Particle Shape & $\begin{array}{c}\text { Particle Thermal } \\
\text { Conductivity }\end{array}$ & Base Fluid Type & Temperature & $\begin{array}{c}\text { Preparation } \\
\text { Technique } \\
\end{array}$ \\
\hline & & & & 4 & 21 & & & & & & & \\
\hline \multirow[t]{4}{*}[76]{} & 2002 & $\mathrm{Al}_{2} \mathrm{O}_{3} / 60.4$ & Water & 5 & 23 & & & & & & & \\
\hline & & & EG & 5 & 30 & & & & & & & \\
\hline & & & PO & 5 & 38 & $\checkmark$ & & & & $\checkmark$ & & $\checkmark$ \\
\hline & & & Glycerol & 5 & 27 & & & & & & & \\
\hline \multirow[t]{3}{*}{ [77] } & 2003 & MWCNT / & DI & 1 & 7 & & & & & & & \\
\hline & & $\varnothing 15 \times 30,000$ & EG & 1 & 12.7 & $\checkmark$ & & $\checkmark$ & & $\checkmark$ & & \\
\hline & & & $\mathrm{DE}$ & 1 & 19.6 & & & & & & & \\
\hline \multirow[t]{3}{*}{ [78] } & 2003 & $\mathrm{Au} / 10-20$ & Water & 0.00026 & 21 & & & & & & & \\
\hline & & & Toluene & 0.011 & 8.8 & $\checkmark$ & & & & & $\checkmark$ & \\
\hline & & $\mathrm{Ag} / 10-20$ & Water & 0.001 & 16.5 & & & & & & & \\
\hline \multirow[t]{2}{*}{ [39] } & 2003 & $\mathrm{Al}_{2} \mathrm{O}_{3} / 38.4$ & Water & 4 & 24 & & & & & & & \\
\hline & & $\mathrm{CuO} / 28.6$ & & 4 & 36 & $\checkmark$ & & & $\checkmark$ & & $\checkmark$ & \\
\hline \multirow[t]{2}{*}[79]{} & 2004 & MWCNT / Ø20- & Water & 0.84 & 21 & & & & & & & \\
\hline & & $\begin{array}{r}60 \times(\mathrm{few} \\
\left.\text { tens } \times 10^{3}\right)\end{array}$ & & & & $\checkmark$ & & & & & $\checkmark$ & \\
\hline \multirow[t]{2}{*}[24]{} & 2005 & DWCNT / Ø5 & Water & 1 & 8 & & & & & & & \\
\hline & & $\begin{array}{c}\text { MWCNT / } \\
\emptyset 130 \times 10000\end{array}$ & & 0.6 & 34 & & & $\checkmark$ & & & & $\checkmark$ \\
\hline \multirow[t]{3}{*}[80]{} & 2005 & $\mathrm{Al}_{2} \mathrm{O}_{3} / 11$ & Water & 1 & 9 & & & & & & & \\
\hline & & $\mathrm{Al}_{2} \mathrm{O}_{3} / 47$ & & 1 & 2 & & $\checkmark$ & & & & $\checkmark$ & \\
\hline & & $\mathrm{Al}_{2} \mathrm{O}_{3} / 150$ & & 1 & 0.5 & & & & & & & \\
\hline$[25]$ & 2005 & $\mathrm{Fe} / 10$ & EG & 0.55 & 18 & $\checkmark$ & & & & & & $\checkmark$ \\
\hline \multirow[t]{2}{*}{ [26] } & 2005 & MWCNT / & EG & 1 & 12.4 & & & & & & & \\
\hline & & $\varnothing 20 \sim 50$ & EO & 1 & 8.5 & $\checkmark$ & & $\checkmark$ & & $\checkmark$ & & \\
\hline \multirow[t]{2}{*}{ [27] } & 2005 & $\begin{array}{l}\mathrm{TiO}_{2} / 15 \\
\text { (sphere) }\end{array}$ & DI & 5 & 30 & & & & & & & \\
\hline & & $\begin{array}{c}\mathrm{TiO}_{2} / \varnothing 10 \times 40 \\
\text { (cylinder) }\end{array}$ & & 5 & 33 & $\checkmark$ & & $\checkmark$ & & & & \\
\hline [81] & 2005 & $\mathrm{Al}_{2} \mathrm{O}_{3} / 10$ & Water & 0.5 & 100 & & $\checkmark$ & & & & $\checkmark$ & \\
\hline$[82]$ & 2006 & $\begin{array}{c}\mathrm{Al}_{70} \mathrm{Cu}_{30} / 20- \\
40\end{array}$ & EG & 2.5 & 125 & $\checkmark$ & $\checkmark$ & & & & & \\
\hline \multirow[t]{4}{*}{ [83] } & 2006 & Ag-Cu / 10 & PO & 0.003 & 15 & & & & & & & \\
\hline & & & & 0.006 & 33 & & & & & & & \\
\hline & & & & 0.009 & 12 & $\checkmark$ & & & & & & \\
\hline & & & & 0.015 & 0.02 & & & & & & & \\
\hline$[28]$ & 2006 & MWCNT / Ø40 & Water & 0.49 & 80 & $\checkmark$ & & $\checkmark$ & & & $\checkmark$ & \\
\hline
\end{tabular}




\begin{tabular}{|c|c|c|c|c|c|c|c|c|c|c|c|c|}
\hline \multirow[b]{2}{*}{ Ref. } & \multirow[b]{2}{*}{ Year } & \multirow{2}{*}{$\begin{array}{l}\text { Particles Type / } \\
\text { Size (nm) }\end{array}$} & \multirow[b]{2}{*}{ Base-fluid } & \multirow{2}{*}{$\begin{array}{l}\text { Loading } \\
\text { (\% vol.) }\end{array}$} & \multirow{2}{*}{$\begin{array}{c}\text { Enhancement } \\
\text { (\%) }\end{array}$} & \multicolumn{7}{|c|}{ Parameters Investigated } \\
\hline & & & & & & $\begin{array}{c}\text { Particle } \\
\text { Concentration }\end{array}$ & Particle Size & Particle Shape & $\begin{array}{l}\text { Particle Thermal } \\
\text { Conductivity }\end{array}$ & Base Fluid Type & Temperature & $\begin{array}{c}\text { Preparation } \\
\text { Technique }\end{array}$ \\
\hline \multirow[t]{4}{*}[84]{} & 2006 & $\begin{array}{c}\text { MWCNT / Ø10- } \\
30 \times 10,000- \\
50,000\end{array}$ & Water & 1 & 11.3 & & & & & & & \\
\hline & & $\mathrm{CuO} / 33$ & & 1 & 5 & $\checkmark$ & & $\checkmark$ & & $\checkmark$ & & \\
\hline & & $\mathrm{SiO}_{2} / 12$ & & 1 & 3 & & & & & & & \\
\hline & & $\mathrm{CuO} / 33$ & EG & 1 & 9 & & & & & & & \\
\hline \multirow[t]{2}{*}{ [85] } & 2006 & $\mathrm{CuO} / 29$ & Water & 6 & 52 & & & & & & & \\
\hline & & $\mathrm{Al}_{2} \mathrm{O}_{3} / 36$ & & 10 & 30 & $\checkmark$ & & & & & $\checkmark$ & \\
\hline \multirow[t]{3}{*}{ [44] } & 2006 & $\mathrm{Au} / 4$ & Ethanol & 0.018 & 1.3 & & & & & & & \\
\hline & & $\mathrm{Au} / 2$ & Toluene & 0.024 & 1.4 & & & & & & & \\
\hline & & $\begin{array}{l}\mathrm{C}_{60}-\mathrm{C}_{70} \\
\text { fullerenes }\end{array}$ & & 0.378 & 0.816 & $\checkmark$ & & $\checkmark$ & & & & \\
\hline$[86]$ & 2006 & $\mathrm{TiO}_{2} / 34$ & Water & 6.8 & 6 & $\checkmark$ & & & & & & \\
\hline [87] & 2007 & $\mathrm{TiO}_{2} / 20$ & Water & 2 & 4.2 & $\checkmark$ & $\checkmark$ & & & & & \\
\hline \multirow[t]{13}{*}{ [29] } & 2007 & $\mathrm{Al}_{2} \mathrm{O}_{3} / 38$ & Water & 3 & 8 & & & & & & & \\
\hline & & & EG & 3 & 10.6 & & & & & & & \\
\hline & & $\mathrm{TiO}_{2} / 10$ & Water & 3 & 11.4 & & & & & & & \\
\hline & & & $\mathrm{EG}$ & 3 & 15.4 & & & & & & & \\
\hline & & $\mathrm{TiO}_{2} / 34$ & Water & 3 & 8.7 & & & & & & & \\
\hline & & & $\mathrm{EG}$ & 3 & 12.3 & & & & & & & \\
\hline & & $\mathrm{TiO}_{2} / 70$ & Water & 3 & 6.4 & $\checkmark$ & $\checkmark$ & & & $\checkmark$ & & \\
\hline & & & $\mathrm{EG}$ & 3 & 7.5 & & & & & & & \\
\hline & & $\mathrm{ZnO} / 10$ & Water & 3 & 14.2 & & & & & & & \\
\hline & & $\mathrm{ZnO} / 30$ & Water & 3 & 11.5 & & & & & & & \\
\hline & & & $\mathrm{EG}$ & 3 & 21 & & & & & & & \\
\hline & & $\mathrm{ZnO} / 60$ & Water & 3 & 7.3 & & & & & & & \\
\hline & & & $\mathrm{EG}$ & 3 & 10.7 & & & & & & & \\
\hline \multirow[t]{2}{*}{ [88] } & 2007 & $\mathrm{Al}_{2} \mathrm{O}_{3} / 36$ & Water & 6 & 28 & 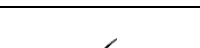 & 1 & & & & 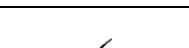 & \\
\hline & & $\mathrm{Al}_{2} \mathrm{O}_{3} / 47$ & & 6 & 26 & $\checkmark$ & $\checkmark$ & & & & $\checkmark$ & \\
\hline \multirow[t]{4}{*}{ [31] } & 2007 & $\mathrm{TiO}_{2} / 25$ & DI & 1 & 14.4 & & & & & & & \\
\hline & & $\mathrm{Al}_{2} \mathrm{O}_{3} / 48$ & & 1 & 4 & & & & & & & \\
\hline & & $\mathrm{Fe} / 10$ & EG & 0.3 & 16.5 & $\checkmark$ & $\checkmark$ & & $\checkmark$ & & & \\
\hline & & $\mathrm{WO}_{3} / 38$ & & 0.3 & 13.8 & & & & & & & \\
\hline \multirow[t]{4}{*}{ [32] } & 2007 & $\mathrm{Au} / 1.65$ & Toluene & 0.003 & 8 & & & & & & & \\
\hline & & $\mathrm{Al}_{2} \mathrm{O}_{3} / 20$ & Water & 14.6 & 22 & 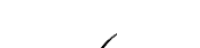 & & & 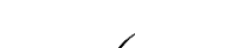 & & & \\
\hline & & $\mathrm{TiO}_{2} / 40$ & & 2.6 & 6.5 & $\checkmark$ & & $\checkmark$ & $\checkmark$ & & & \\
\hline & & $\mathrm{CuO} / 33$ & & 4.18 & 16.5 & & & & & & & \\
\hline
\end{tabular}




\begin{tabular}{|c|c|c|c|c|c|c|c|c|c|c|c|c|}
\hline \multirow{3}{*}{ Ref. } & \multirow{3}{*}{ Year } & \multirow{3}{*}{$\begin{array}{c}\text { Particles Type / } \\
\text { Size (nm) } \\
\text { CNF / } \\
150 \emptyset \times 10,000\end{array}$} & \multirow{3}{*}{ Base-fluid } & \multirow{2}{*}{$\begin{array}{l}\text { Loading } \\
\text { (\% vol.) }\end{array}$} & \multirow{2}{*}{$\begin{array}{c}\text { Enhancement* } \\
\text { (\%) }\end{array}$} & \multicolumn{7}{|c|}{ Parameters Investigated } \\
\hline & & & & & & $\begin{array}{c}\text { Particle } \\
\text { Concentration }\end{array}$ & Particle Size & Particle Shape & $\begin{array}{l}\text { Particle Thermal } \\
\text { Conductivity }\end{array}$ & Base Fluid Type & Temperature & $\begin{array}{c}\text { Preparation } \\
\text { Technique }\end{array}$ \\
\hline & & & & 0.89 & 41.4 & & & & & & & \\
\hline \multirow[t]{6}{*}{ [89] } & 2007 & $\begin{array}{c}\text { MWCNT / Ø10- } \\
30 \times 10,000- \\
50,000\end{array}$ & Water & 1 & 7 & \multirow{6}{*}{$\checkmark$} & \multirow{6}{*}{$\checkmark$} & \multirow{6}{*}{$\checkmark$} & \multirow{6}{*}{$\checkmark$} & \multirow{6}{*}{$\checkmark$} & & \multirow{6}{*}{$\checkmark$} \\
\hline & & $\mathrm{CuO} / 33$ & & 1 & 5 & & & & & & & \\
\hline & & $\mathrm{SiO}_{2} / 12$ & & 1 & 3.2 & & & & & & & \\
\hline & & $\mathrm{CuO} / 33$ & EG & 1 & 9.1 & & & & & & & \\
\hline & & $\begin{array}{c}\text { MWCNT / Ø10- } \\
30 \times 10,000- \\
50,000\end{array}$ & MO & 0.5 & 8.7 & & & & & & & \\
\hline & & $\begin{array}{c}\mathrm{C}_{60}-\mathrm{C}_{70} \\
\text { fullerenes / } 10 \\
\end{array}$ & & 5 & 6 & & & & & & & \\
\hline \multirow[t]{8}{*}{ [90] } & 2008 & $\mathrm{Al}_{2} \mathrm{Cu} / 31$ & Water & 2 & 96 & \multirow{8}{*}{$\checkmark$} & \multirow{8}{*}{$\checkmark$} & & & \multirow{8}{*}{$\checkmark$} & & \\
\hline & & $\mathrm{Al}_{2} \mathrm{Cu} / 101$ & \multirow{7}{*}{ EG } & 2 & 61 & & & & & & & \\
\hline & & $\mathrm{Ag}_{2} \mathrm{Al} / 33$ & & 2 & 106 & & & & & & & \\
\hline & & $\mathrm{Ag}_{2} \mathrm{Al} / 120$ & & 2 & 75 & & & & & & & \\
\hline & & $\mathrm{Al}_{2} \mathrm{Cu} / 31$ & & 2 & 84 & & & & & & & \\
\hline & & $\mathrm{Al}_{2} \mathrm{Cu} / 101$ & & 2 & 56 & & & & & & & \\
\hline & & $\mathrm{Ag}_{2} \mathrm{Al} / 33$ & & 2 & 96 & & & & & & & \\
\hline & & $\mathrm{Ag}_{2} \mathrm{Al} / 120$ & & 2 & 62 & & & & & & & \\
\hline \multirow[t]{2}{*}[34]{} & 2008 & $\mathrm{TiO}_{2} / 15$ & EG & 5 & 18 & \multirow[b]{2}{*}{$\checkmark$} & & & \multirow[b]{2}{*}{$\checkmark$} & \multirow{2}{*}{\multicolumn{2}{|c|}{$\checkmark$}} & \\
\hline & & $\mathrm{Al} / 80$ & & 5 & 45 & & & & & & & \\
\hline \multirow[t]{2}{*}[40]{} & 2008 & $\mathrm{Al}_{2} \mathrm{O}_{3} / 45$ & DI & 4 & 13.3 & \multirow[b]{2}{*}{$\checkmark$} & & & & & & \\
\hline & & & EG & 4 & 9.7 & & & & & & & \\
\hline [91] & 2008 & $\mathrm{Fe}_{3} \mathrm{O}_{4} / 6.7$ & Kerosene & $<2 \%$ & 300 & $\checkmark$ & & & & & & $\checkmark$ \\
\hline \multirow[t]{2}{*}{ [35] } & 2009 & $\mathrm{Al}_{2} \mathrm{O}_{3} / 282$ & Water & 4 & 17.7 & \multirow[b]{2}{*}{$\checkmark$} & & & & & & \\
\hline & & $\mathrm{Al}_{2} \mathrm{O}_{3} / 282$ & EG & 3 & 16.3 & & $\checkmark$ & & & & & \\
\hline [92] & 2009 & $\mathrm{TiO}_{2} / 21$ & Water & 2 & 7 & $\checkmark$ & & & & & $\checkmark$ & \\
\hline$[55]$ & 2009 & $\mathrm{Al}_{2} \mathrm{O}_{3} / 36$ & Water & 18 & 31 & & & & & & & \\
\hline & & $\mathrm{Al}_{2} \mathrm{O}_{3} / 47$ & & 18 & 31 & $\checkmark$ & $\checkmark$ & & & & $\checkmark$ & \\
\hline & & $\mathrm{CuO} / 29$ & & 16 & 24 & & & & & & & \\
\hline [93] & 2009 & $\mathrm{TiO}_{2} / 21$ & DI & 3 & 7.2 & $\checkmark$ & & & & & $\checkmark$ & \\
\hline [94] & 2009 & $\mathrm{Al}_{2} \mathrm{O}_{3} / 15-50$ & Water & 4 & 10.1 & $\checkmark$ & & & & & & $\checkmark$ \\
\hline [95] & 2010 & $\mathrm{Fe}_{3} \mathrm{O}_{4} / 15-22$ & Water & 3 & 11.5 & $\checkmark$ & & & & & $\checkmark$ & $\checkmark$ \\
\hline [96] & 2010 & $\mathrm{Al}_{2} \mathrm{O}_{3} / 12$ & Water & 4 & 5.4 & $\checkmark$ & $\checkmark$ & & & $\checkmark$ & & \\
\hline
\end{tabular}




\begin{tabular}{|c|c|c|c|c|c|c|c|c|c|c|c|c|}
\hline \multirow{5}{*}{ Ref. } & \multirow{5}{*}{ Year } & \multirow{2}{*}{$\begin{array}{l}\text { Particles Type / } \\
\text { Size (nm) }\end{array}$} & \multirow[b]{2}{*}{ Base-fluid } & \multirow{2}{*}{$\begin{array}{l}\text { Loading } \\
\text { (\% vol.) }\end{array}$} & \multirow{2}{*}{$\begin{array}{c}\text { Enhancement* } \\
(\%)\end{array}$} & \multicolumn{7}{|c|}{ Parameters Investigated } \\
\hline & & & & & & $\begin{array}{c}\text { Particle } \\
\text { Concentration }\end{array}$ & Particle Size & Particle Shape & $\begin{array}{l}\text { Particle Thermal } \\
\text { Conductivity }\end{array}$ & Base Fluid Type & Temperature & $\begin{array}{c}\text { Preparation } \\
\text { Technique }\end{array}$ \\
\hline & & & $\overline{E G}$ & 4 & 14.3 & & & & & & & \\
\hline & & $\mathrm{Al}_{2} \mathrm{O}_{3} / 10$ & EG-Water & 3 & 11.3 & & & & & & & \\
\hline & & $\mathrm{Al}_{2} \mathrm{O}_{3} / 50$ & (50:50 wt.\%) & 3 & 10.4 & & & & & & & \\
\hline [97] & 2010 & $\mathrm{Fe}_{3} \mathrm{O}_{4} / 15$ & Kerosene & 1 & 34.6 & $\checkmark$ & & & & & $\checkmark$ & \\
\hline [98] & 2011 & $\mathrm{SiC} / 100$ & DI & 3 & 7.2 & $\checkmark$ & & & & & & \\
\hline [99] & 2012 & $\begin{array}{c}\text { SWCNT / 100- } \\
600\end{array}$ & Water & 0.3 & 12.1 & $\checkmark$ & & & & & $\checkmark$ & \\
\hline [100] & 2012 & $\begin{array}{c}\text { SWCNT / 100- } \\
600\end{array}$ & EG & 0.21 & 15.5 & $\checkmark$ & & & & & $\checkmark$ & \\
\hline \multirow[t]{2}{*}{ [101] } & 2012 & $\mathrm{CuO} / 25$ & Water & 7.5 & 32.3 & & & & & & & \multirow{2}{*}{$\checkmark$} \\
\hline & & & MEG & 7.5 & 21.3 & $\checkmark$ & & & & & & \\
\hline [102] & 2012 & $\begin{array}{c}\text { MWCNT / Ø5- } \\
20\end{array}$ & HTO & 2 & 15 & $\checkmark$ & & & & & $\checkmark$ & \\
\hline \multirow[t]{2}{*}{ [103] } & 2013 & $\mathrm{SiO}_{2} / 10$ & Water & 1.2 & 11 & & & & & & & \\
\hline & & $\mathrm{SiO}_{2} / 60$ & & 1.2 & 13 & $\checkmark$ & & & & & & \\
\hline \multirow[t]{2}{*}{ [104] } & 2013 & $\mathrm{Al}_{2} \mathrm{O}_{3} / 36.5$ & EG-Water & 8 & 17.89 & & & & & & & \\
\hline & & $\mathrm{CuO} / 27$ & (50:50 wt.\%) & 8 & 24.56 & $\checkmark$ & & & & & $\checkmark$ & \\
\hline \multirow[t]{4}{*}{ [105] } & 2014 & $\gamma-\mathrm{Al}_{2} \mathrm{O}_{3} / 13$ & Water & 6 & 14.5 & & & & & & & \\
\hline & & $\mathrm{SiO}_{2} / 15$ & & 6 & 10.8 & & & & & & & \\
\hline & & $\mathrm{TiO}_{2} / 13.5$ & & 4 & 15.1 & $\checkmark$ & & & & & & \\
\hline & & $\alpha-\mathrm{Al}_{2} \mathrm{O}_{3} / 24.4$ & & 6 & 18.6 & & & & & & & \\
\hline [106] & 2014 & $\begin{array}{c}\mathrm{Sn}-\mathrm{SiO}_{2} / 50- \\
100\end{array}$ & TH66 & 5 & 13 & $\checkmark$ & & & $\checkmark$ & & & \\
\hline [107] & 2015 & $\mathrm{Al}_{2} \mathrm{O}_{3} / 40$ & Water & 4 & 14.4 & $\checkmark$ & & & & & $\checkmark$ & $\checkmark$ \\
\hline [108] & 2015 & $\begin{array}{c}\text { DWCNT / Ø3 + } \\
\text { Zn0 / 10-30 } \\
(50: 50 \text { vol.\%) }\end{array}$ & $\begin{array}{c}\text { EG-Water } \\
(60: 40 \text { wt. } \%)\end{array}$ & 1 & 33 & $\checkmark$ & & & & & $\checkmark$ & \\
\hline [109] & 2015 & $\mathrm{NiFe}_{2} \mathrm{O}_{4} / 8$ & DI & 2 & 17.2 & $\checkmark$ & & & & & $\checkmark$ & \\
\hline [110] & 2015 & AG / 5-25 & DI & 0.5 & 16 & $\checkmark$ & & & & & & $\checkmark$ \\
\hline \multirow[t]{3}{*}{ [111] } & 2015 & $\mathrm{Al}_{2} \mathrm{O}_{3} / 13$ & $\begin{array}{c}\text { EG-Water } \\
(60: 40 \text { wt. } \%)\end{array}$ & 2 & 8.4 & & & & & & & \\
\hline & & & $\begin{array}{c}\text { EG-Water } \\
\text { (50:50 wt. } \%)\end{array}$ & 2 & 12.6 & $\checkmark$ & & & & $\checkmark$ & $\checkmark$ & \\
\hline & & & $\begin{array}{c}\text { EG-Water } \\
\text { (40:60 wt. } \%)\end{array}$ & 2 & 16.2 & & & & & & & \\
\hline [112] & 2015 & $\mathrm{MgO} / 40$ & $\begin{array}{c}\text { EG-Water } \\
\text { (40:60 wt. } \%)\end{array}$ & 3 & 34.43 & $\checkmark$ & & & $\checkmark$ & & $\checkmark$ & \\
\hline
\end{tabular}




\begin{tabular}{|c|c|c|c|c|c|c|c|c|c|c|c|c|}
\hline \multirow[b]{2}{*}{ Ref. } & \multirow[b]{2}{*}{ Year } & \multirow[b]{2}{*}{$\begin{array}{l}\text { Particles Type / } \\
\text { Size (nm) }\end{array}$} & \multirow[b]{2}{*}{ Base-fluid } & \multirow[b]{2}{*}{$\begin{array}{l}\text { Loading } \\
\text { (\% vol.) }\end{array}$} & \multirow[b]{2}{*}{$\begin{array}{l}\text { Enhancement } \\
\text { (\%) }\end{array}$} & \multicolumn{7}{|c|}{ Parameters Investigated } \\
\hline & & & & & & $\begin{array}{c}\text { Particle } \\
\text { Concentration }\end{array}$ & Particle Size & Particle Shape & $\begin{array}{l}\text { Particle Thermal } \\
\text { Conductivity }\end{array}$ & Base Fluid Type & Temperature & $\begin{array}{c}\text { Preparation } \\
\text { Technique }\end{array}$ \\
\hline [113] & 2016 & $\mathrm{SiC} / 30$ & DO & 0.8 & 7.36 & $\checkmark$ & & & & & $\checkmark$ & $\checkmark$ \\
\hline [114] & 2016 & $\mathrm{ZnO} / 50$ & EG & 2.4 & 13 & $\checkmark$ & & & & & $\checkmark$ & $\checkmark$ \\
\hline \multirow[t]{3}{*}{ [115] } & 2016 & $\mathrm{CuO} / 55-66$ & Water & 2 & 24 & & & & & & & \\
\hline & & & EG & 2 & 21 & $\checkmark$ & & & & $\checkmark$ & $\checkmark$ & $\checkmark$ \\
\hline & & & EO & 2 & 14 & & & & & & & \\
\hline [116] & 2016 & AG / 20 & HTO & 0.171 & 41 & $\checkmark$ & & & & & $\checkmark$ & \\
\hline [117] & 2016 & $\mathrm{TiO}_{2} / 5$ & EG & 7 & 19.52 & $\checkmark$ & & & & & $\checkmark$ & \\
\hline [118] & 2016 & AG / 10 & HTO & 0.6 & 36.3 & $\checkmark$ & & & & & $\checkmark$ & \\
\hline \multirow[t]{4}{*}{ [119] } & 2016 & $\begin{array}{c}\text { S-SWCNT / } \\
\varnothing 1-2 \times 1000- \\
3000\end{array}$ & Water & 048 & 8.1 & & & & & & & \\
\hline & & L-SWCNT / & & 0.48 & 16.2 & & & & & & & \\
\hline & & $\begin{array}{c}\varnothing 1-2 \times 5000- \\
30,000\end{array}$ & & & & $\checkmark$ & & & & & $\checkmark$ & \\
\hline & & $\begin{array}{c}\text { MWCNT / } \\
\varnothing 10- \\
30 \times 30,000\end{array}$ & & 0.48 & 5 & & & & & & & \\
\hline
\end{tabular}

${ }^{*}$ Enhancement \% is calculated based on: Enhancement $(\%)=\left[\left(k_{n f}-k_{b b} f\right) / k_{b} f{ }^{* 100}\right.$ 


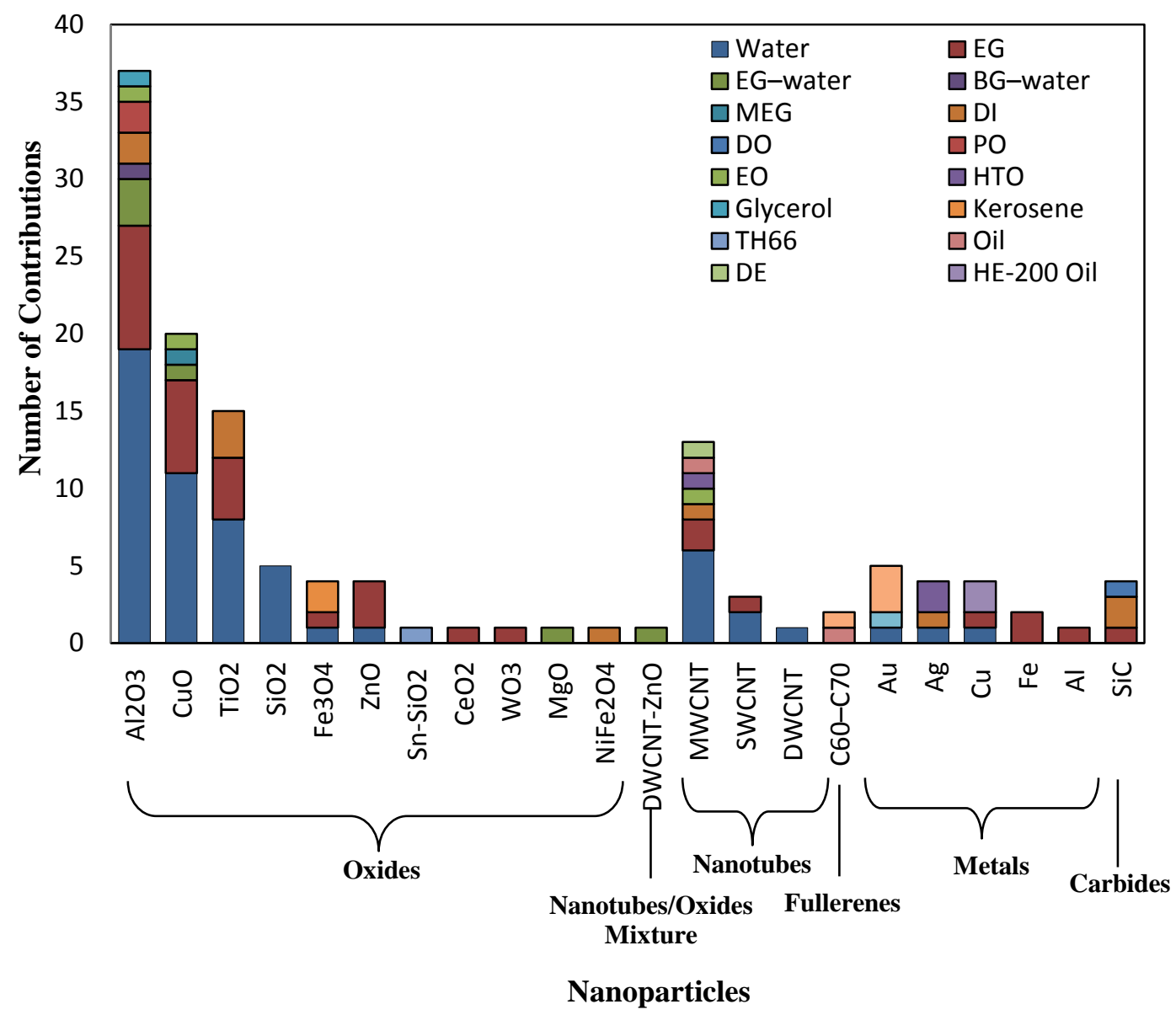

Fig. 1 Number of contributions vs. nanoparticles (according to this review)

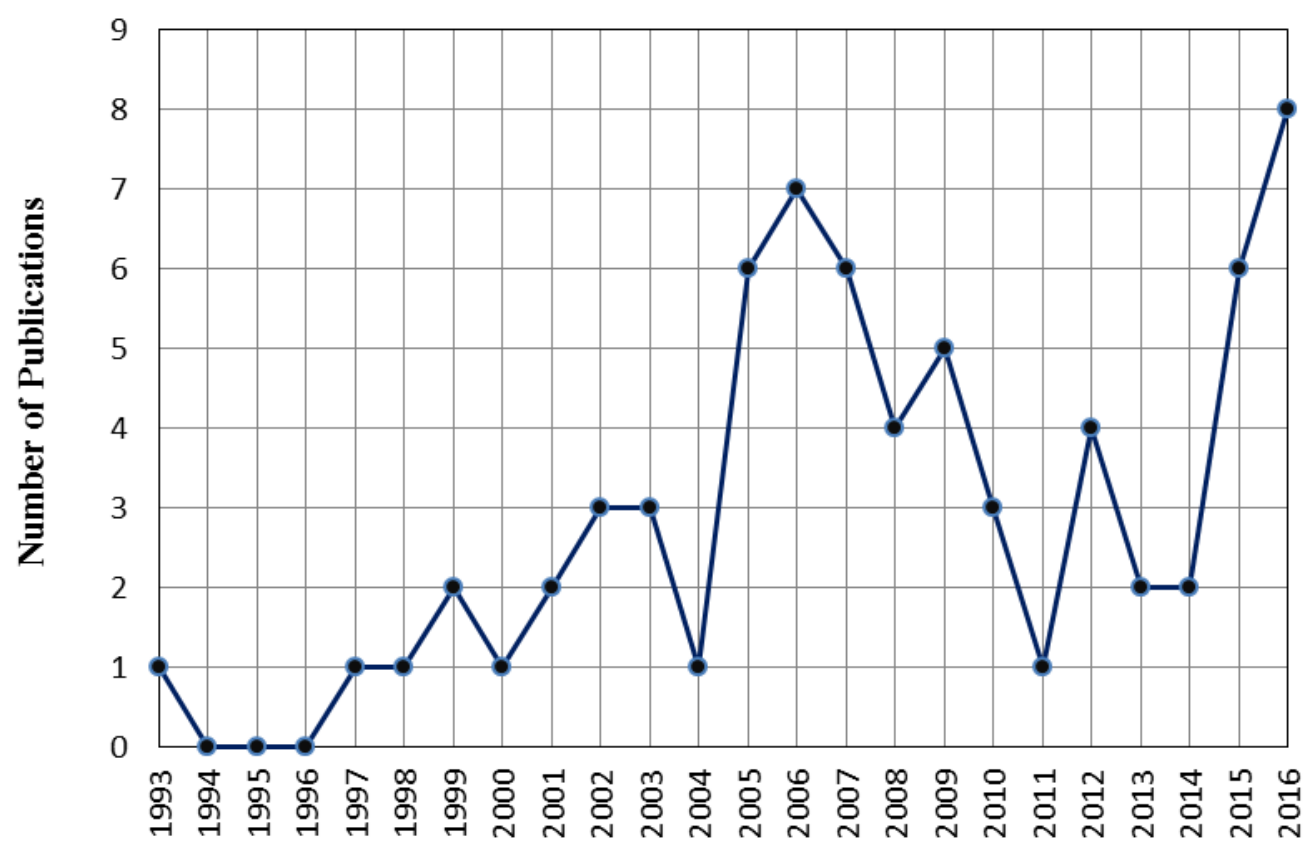

Year

Fig. 2 Number of experimental publications dealing with thermal conductivity in nanofluids per year (according to this review) 


\subsection{Gas-Based Nanofluids}

In such type, nanoparticles are dispersed in gaseous base fluids. This mixture is also known as aerosols [120,121]. Studying heat transfer characteristics of aerosols has a great importance not only for thermal applications, but also for environmental and climate studies [121-123]. Although natural convection heat transfer in gas-based nanofluids is investigated [124-127], limited research work was done in the field of thermal conductivity enhancement and forced convection of aerosol nanoparticle systems [128].

In the field of thermal conductivity enhancement, Bibire et al. [129] carried out a mathematical analysis to study thermal and electrical conductivities of atmospheric aerosols. They applied the scale relativity model [130]. They found that the enhancement in the effective conductivity is inversely proportional to atmospheric nanoparticle diameter for a given atmospheric nanofluid.

\section{Parameters Affecting Nanofluids Thermal Conductivity}

According to literature listed in

, there are different investigated parameters affecting thermal conductivity of nanofluids, as illustrated in Fig. 3. In this section, such parameters will be discussed based on past work observations.

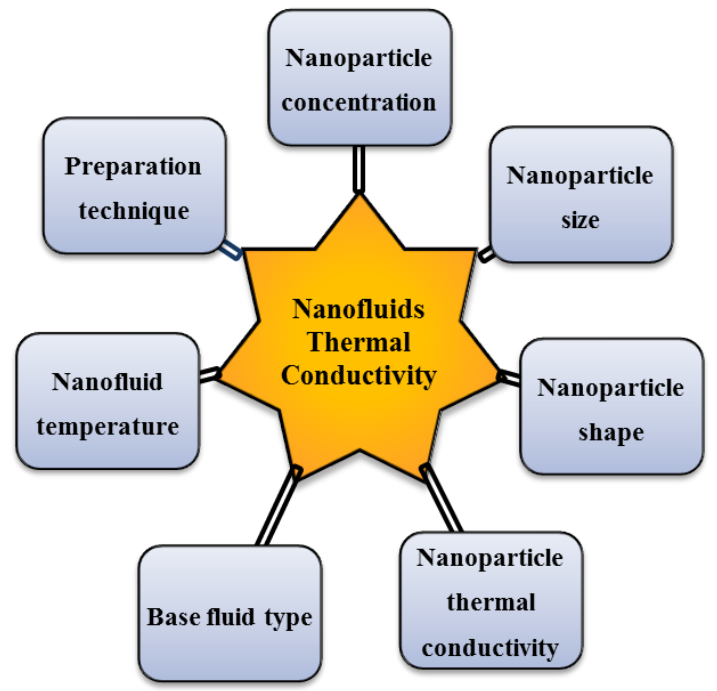

Fig. 3 Parameters affecting the thermal conductivity of nanofluids

\subsection{Nanoparticle Concentration}

Many researchers investigated the effect of volumetric loading of nanoparticles in suspension on thermal conductivity enhancement. Most of them found that the more nanoparticles concentration, the more enhanced thermal conductivity of the suspension. Some of researchers found the relation to be nonlinear $[25,79,86,87]$, while others found it linear [22,23,2629,31,32,34,35,39,40,55,69-78,82,84,85,88-102,104-119,131133].

However, this relation is associated with a limited nanoparticle loading. This fact was observed by Ceylan et al. [83], who tested suspended Ag-Cu alloy nanoparticles $(10 \mathrm{~nm})$ in PO. They found that the thermal conductivity enhancement increases with increasing volumetric loading until a certain peak point. Beyond this point the thermal conductivity decreases until it reaches its value for the base fluid. On the other hand, the proportionality relationship between nanoparticles volume fraction and thermal conductivity enhancement could not be proven by Putnam et al. [44]. They investigated thermal conductivity of Au suspensions in ethanol and toluene and fullerene in toluene for very low loadings ( $<<1 \%$ vol.). Their results showed fluctuating small enhancements. This may be attributed to their inability to synthesize and study well-dispersed nanoparticle suspensions, especially for nanofluids with particles concentrations higher than $1 \%$ vol.

\subsection{Nanoparticle Size}

Particles size plays a great role in enhancing thermal conductivity of nanofluids. It represents the most significant difference between nanofluids and micron-sized suspensions. The effect of nanoparticles size is not limited to suspension stability, but extends to include thermal properties. The effect on enhancing thermal conductivity of nanofluids was studied frequently. It was found by Lee et al. [71] that the effective thermal conductivity of nanofluids increases with decreasing particle size. They observed this relation through comparing their results with reported data provided by Masuda et al. [22]. This fact was confirmed later by Wang et al. [43], who compared their results with Masuda et al. [22] and Lee et al. [71] results. Another proof of the validity of this conclusion comes through comparing Xuan and $\mathrm{Li}$ [72] results with Eastman et al. [69] ones, as the larger particle size of $\mathrm{Cu}$ used by Xuan and Li [72] leaded to drop the enhancement from $44 \%$ to $12 \%$ despite the relatively higher concentration than used by Eastman et al. [69]. In the same context, achieving a near amount of enhancement by $100 \mathrm{~nm}$ compared to $35 \mathrm{~nm}$, it was required to raise the concentration from $0.052 \mathrm{vol} \%$ to 7.5 vol.\%. This inverse relation between particle size and thermal conductivity enhancement was proven by many authors $[29,31,55,75,80-82,87,88,90,96,119]$.

However, this relation is not always true, especially if particle shape parameter is interfered. Based on [23] and [89] results, large cylindrical-shaped and MWCNT nanoparticles can enhance the conductivity more than smaller spherical-shaped ones if dispersed in the same base fluid. Moreover, Pak and Cho [70] recommended selecting larger particles to enhance heat transfer performance, based on their results. This finding was confirmed later by and Hwang et al. [89] Beck et al. [35]. Hwang et al. [89] results showed that $\mathrm{CuO}$ (33nm) enhanced thermal conductivity higher than $\mathrm{SiO}_{2}(12 \mathrm{~nm})$ for the same base fluid and concentration. Beck et al. [35], who studied thermal conductivity of $\mathrm{Al}_{2} \mathrm{O}_{3} /$ water and $\mathrm{Al}_{2} \mathrm{O}_{3} / \mathrm{EG}$ nanofluids for particles sizes ranging from 8 to $282 \mathrm{~nm}$, also found that the enhancement of thermal conductivity decreases as the particle size decreases below about $50 \mathrm{~nm}$. They attributed this to a decrease in the thermal conductivity of the nanoparticles as a result of increased phonon scattering effect.

\subsection{Nanoparticle Shape}

The effect of nanoparticles shape was studied by Xie et al. [23].Their results indicated that the cylindrical-shaped nanoparticles showed higher enhancement than sphericalshaped ones for the same base fluid, despite their larger average size. This conclusion was confirmed later by [26$28,77,84]$ results. Moreover, the increase in length-to-diameter ratio of the dispersed nanotubes leads to the increase of the thermal conductivity enhancement [24,32]. In the same 
context, the effective thermal conductivity measured by Choi et al. [74] showed that nanotubes (MWCNT) yield an anomalously nonlinear increase in the conductivity compared to predicted linear behavior. On the other hand, fullerenes, which are carbon molecules in the form of a hollow sphere, ellipsoid, tube and many other shapes [134], showed lower enhancement. This result was concluded by Putnam et al. [44] who dispersed $\mathrm{C}_{60}-$ $\mathrm{C}_{70}$ fullerenes in toluene and compared their effect on enhancement of thermal conductivity against dispersing $\mathrm{Au}$ nanoparticles. Their results indicated that fullerenes showed lower enhancement than $\mathrm{Au}$ at loadings $<<1 \%$ vol. However, these data was not confirmed for higher volumetric loadings. Another lower enhancement of fullerenes in mineral oil nanofluids was observed by Hwang et al. [89] when compared its enhancement with MWCNT in the same base fluid, even at higher concentration.

\subsection{Nanoparticle Thermal Conductivity}

Select nanoparticles having higher thermal conductivity was recommended by Pak and Cho [70] to enhance heat transfer performance. This finding was confirmed later by $[32,34,39,71,89]$ results. In the same context, by comparing [111] and [112] results, it is clear to find that for the same base fluid, MgO showed significant higher thermal conductivity enhancement compared to the A1203 system, despite the larger $\mathrm{MgO}$ particle size $(40 \mathrm{~nm})$ compared to $(13 \mathrm{~nm})$ for A1203 nanoparticles. This comparison indicates that the particle thermal conductivity has a stronger effect than particle size. According to Eastman et al. [73], nanofluids containing metallic particles can achieve a large improvement in effective conductivity compared to either base fluids or nanofluids containing oxide particles. Moreover, Cingarapu et al. [106] found that addition of ceramics encapsulated phase change nanoparticles enhances thermal conductivity of nanofluids than conventional HTFs. They also observed that such type of particles improved the heat transfer and thermal storage properties of HTFs. However, Yoo et al. [31] reported that determining nanofluids thermal conductivity was not primarily affected by suspended nanoparticles thermal. Thermal conductivities of some materials used as nanoparticles are listed in Table 2.

Table 2 Thermal conductivities of some materials used as nanoparticles

\begin{tabular}{ccc}
\hline Particle & Thermal conductivity $(\mathrm{W} / \mathrm{mK})$ & Reference \\
\hline $\mathrm{Al}_{2} \mathrm{O}_{3}$ & 40 & {$[135]$} \\
$\mathrm{CuO}$ & 76.5 & {$[89]$} \\
$\mathrm{Fe}_{2} \mathrm{O}_{3}$ & 6 & {$[136]$} \\
$\mathrm{MgO}_{\mathrm{SiO}}$ & 54.9 & {$[137]$} \\
$\mathrm{TiO}_{2}$ & $1.34-1.38$ & {$[89,138]$} \\
$\mathrm{ZnO}$ & 8.4 & {$[29]$} \\
$\mathrm{Ag}$ & 29 & {$[29]$} \\
$\mathrm{Al}$ & 429 & {$[139]$} \\
$\mathrm{Au}$ & $238-273$ & {$[138,139]$} \\
$\mathrm{Cu}$ & 310 & {$[139]$} \\
$\mathrm{Fe}$ & 401 & {$[139]$} \\
$\mathrm{MWCNT}$ & $75-80$ & {$[138,139]$} \\
$\mathrm{C}_{60}-\mathrm{C}_{70}$ & $2000 \sim 3000$ & {$[140,141]$} \\
(Fullerene) & 0.4 & {$[89]$} \\
$\mathrm{SiC}$ & 490 & {$[142]$} \\
\hline
\end{tabular}

\subsection{Base Fluid Type}

For the nanofluids using the same nanoparticles, the thermal conductivity improvement was found to be inversely proportional to the base fluid thermal conductivity, regardless nanoparticles shape [29]. This conclusion was achieved and confirmed through observing higher thermal conductivity enhancement for nanofluids with EG as a base fluid compared to others that with water base fluid $[23,71,76,77,84,89,96]$.

In contrast of that conclusion, observations reported by $[26,115]$ indicated that at the same volume fraction, using EG as the base fluid leaded to achieving higher enhancements compared to the enhancement in case of using EO. This conflict was reconfirmed through measurements obtained by $[90,115]$, as water-based nanofluids they tested showed higher enhancement In thermal conductivity compared to EG-based ones at the same volume fraction.

With the beginning of the 2000s, a new research trend emerged. It was based on investigating the use of mixed base fluids instead of conventional ones. In that trend, Beck et al. [96] discussed the use of EG-water mixture as a base fluid with mixing ratio of $50: 50 \%$ by weight. As a result of improved thermal conductivity of such new base fluid, adding nanoparticles showed more enhancement than dispersing in conventional base fluids.

However, using mixed base fluids requires intensive study to select the appropriate mixing ratio, as it dramatically affects thermal conductivity. As an evidence on this fact, Abdolbaqi et al. [131] observed that the enhancement in thermal conductivity by dispersing $\mathrm{Al}_{2} \mathrm{O}_{3}(13 \mathrm{~nm})$ in $\mathrm{BG}$-water base fluid mixed at a ratio of $40: 60 \mathrm{wt} . \%$ was $24 \%$ at 2 vol.\% with temperature of $80^{\circ} \mathrm{C}$. This enhancement dropped to $13 \%$ by opposing the base fluid mixing ratio to be $60: 40 \mathrm{wt} . \%$. This result also agrees with Usri et al. [111] results, who tested $\mathrm{Al}_{2} \mathrm{O}_{3}(13 \mathrm{~nm})$ in EG-water base fluid, as they observed that increasing the EG concentration decreases the thermal conductivity. Thermal conductivities of some base fluids that used in this review as are listed in Table 3.

Table 3 Thermal conductivities of some base fluids

\begin{tabular}{ccc}
\hline Base fluid & $\begin{array}{c}\text { Thermal conductivity } \\
(\mathrm{W} / \mathrm{mK})\end{array}$ & Reference \\
\hline EG & 0.257 & {$[138]$} \\
EO & $0.139-0.146$ & {$[115]$} \\
Ethanol & $0.161-0.171$ & {$[143,144]$} \\
Glycerol & 0.285 & {$[138]$} \\
Kerosene & $0.145-0.168$ & {$[143,145]$} \\
Toluene & 0.133 & {$[142]$} \\
Water & 0.608 & {$[146]$} \\
\hline
\end{tabular}

\subsection{Nanofluid Temperature}

The effect of nanofluid temperature on improving their thermal conductivity has been studied by many researchers. Patel et al. [78] observed that the increments in thermal conductivity of the nanofluids were directly proportional to temperature. This result was in agreement with observations reported later by $[34,39,55,80,81,88,95,99,100,104,109,111-$ $113,115-118,131]$. Even in case of dispersing nanotubes in base fluids, the thermal conductivity enhancement increased with increasing temperature nonlinearly [28,79,102,119,147]. However, Experiments carried out using MWCNT at 
temperatures $60-70^{\circ} \mathrm{C}$ showed destabilization of the nanofluid. However, Li and Peterson [85] concluded that dependence of the effective thermal conductivity on the bulk temperature is much weaker than the dependence on the volume fraction. This conclusion was confirmed later by $[107,108]$ results. In the same context, Beck et al. [96] results indicated that the thermal conductivity enhancement behavior over temperature variation followed closely that of the base fluid. This observation was concluded through studying different base fluids including: water, EG and EG-water mixture. Results reported by $[97,114]$ was in agreement with that conclusion.

In contrast with previous literature, Duangthongsuk and Wongwises [92] results indicated that nanofluid thermal conductivity enhancement slightly decreases with increasing temperature in reverse relation. This result agreed with Turgut et al. [93] findings, despite the insignificant dependence on temperature.

\subsection{Preparation Technique}

Nanofluid dispersion technique plays a great role in stabilizing nanofluid and in improving its thermal conductivity, as it might change the morphology of the nanoparticles $[43,72]$. This section includes investigating the effect of adding different additives to control the $\mathrm{pH}$ value of the prepared nanofluid. In addition, the effect of sonication time will be covered.

Investigating nanofluids $\mathrm{pH}$ value was started in early stage. The effect of adding acid $(\mathrm{HCl})$ or base $(\mathrm{NaOH})$ on electrostatic repulsive forces among the particles was firstly reported by Masuda et al. [22]. This effect kept the nanoparticles dispersed. Xie et al. [76] results showed that the increase in the difference between the $\mathrm{pH}$ value and isoelectric point 1 of $\mathrm{Al}_{2} \mathrm{O}_{3}$ resulted in the enhancement of the effective thermal conductivity. This may be the reason for indicating much higher thermal conductivity than that of Wang et al. [75] for $\mathrm{Al}_{2} \mathrm{O}_{3}-\mathrm{EG}$ nanofluid although the particle size used by Xie et al. [76] was double that of the particles of Wang et al. [75]. Moreover, Xie et al. [76] results indicated that the thermal conductivity enhancement decreases with an increase in $\mathrm{pH}$ value. Zhu et al. [94] observed that that enhancement in thermal conductivity increased with increasing the $\mathrm{pH}$ value up to $8-9$, then the relation turns to be inversely proportional as reported before by Xie et al. [76]. They also recommended using a chemical dispersant combined with adjusting the $\mathrm{pH}$ of the suspension to improve the thermal conductivity. In the same context, Abareshi et al. [95] observed the best crystallinity at a $\mathrm{pH}$ of 9.5 .

On selecting additive type side, Assael et al. [24] also found that the dispersant type affects the enhancement achieved, as they observed larger enhancement in case of adding Nanosperse AQ (NSAQ) compared to Hexadecyltrimethylammonium bromide (CTAB) addition. While Parametthanuwat et al. [110] found that the addition of potassium oleate surfactant $\left(\mathrm{OAK}^{+}\right)$with $1 \mathrm{wt} . \%$ improved the working properties, especially with Ag nanoparticles. Moreover, using oleic acid boosted the rise in the heat transfer rate.

The sonication (or homogenization) time is a critical parameter should be considered in preparing nanofluids, as it plays a major role in stabilizing the suspension [24,110,113-

\footnotetext{
${ }^{1}$ the $\mathrm{pH}$ value at which a molecule carries no net electrical charge [248].
}

115,131]. Khedkar et al. [101] observed that increasing the sonication time enhances the thermal conductivity of the nanofluids until certain limits. They attributed this result to the increased Brownian motion of small particles and agglomeration. However, a moderate sonicating time should be applied, as very low time leaves the nanoparticles bundles untangled, while intensive sonication breaks down the agglomerates size. In case of using nanotubes, longer sonication time decreases the nanotubes length, which leads to quick suspensions precipitation $[24,148,149]$. These results are in agreement with observations reported by Hong et al. [25], who found that thermal conductivity enhancement increased with increasing the sonication time up to 50 minutes while saturation was shown after this point [25]. In 2015, Buonomo et al. [107] proposed a simple procedure to estimate the minimum sonication time required to obtain a stable nanofluid mixtures. Philip et al. [91] achieved an extraordinary thermal conductivity enhancement of $300 \%$ via applying a magnetic field on $\mathrm{Fe}_{3} \mathrm{O}_{4}$ nanoparticles dispersed in base fluid in order to form the linear chain-like structures.

\section{Applications of Nanofluids in Practical Community}

Applications of nanofluids have a wide spectrum in the practical field, so that they require separate review articles to be covered. However, this section focuses on some applications where nanofluids contribution to the thermal conductivity enhancement is significant. Fig. 4 shows different practical applications covered in the present work.

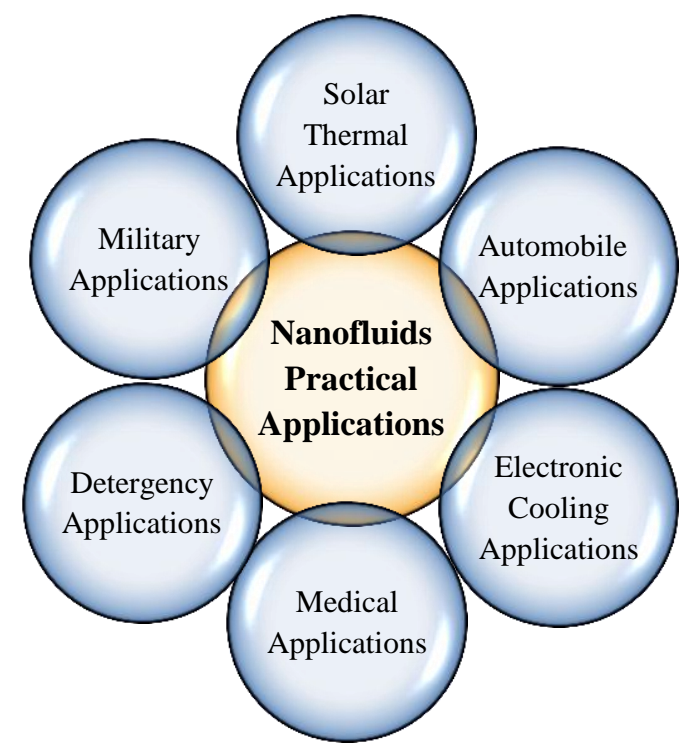

Fig. 4 Practical applications of nanofluids

\subsection{Solar Thermal Applications}

Nanofluids can be used in order to improve the performance of solar thermal devices ranging from the solar water heaters to Concentrated Solar Power (CSP) plants. This is as a result of many advantages of nanofluids over conventional HTFs. These include: small particles size allow them to be fluidized to pass through pumps, micro-channels and piping without any adverse effects. In addition, nanoparticles represent an absorption medium allowing the fluid to absorb solar energy directly [150]. Moreover, by studying photo thermal characteristics of the nanofluids [151-155], they 
showed improved optical properties compared to that of their base fluids [156], such as low emittance in the infrared region [150].

Research papers [157-176] investigated the thermal performance enhancement achieved by using nanofluids in different types of solar collectors. In addition, the optical properties of nanofluids used in solar collectors were studied in [177-185]. Recent CSP systems require high operating temperature and high heat storage capacity [52]. Since nanofluids have improved heat transfer and thermal storage properties [106], they can be used as a HTF in CSP plants rather than conventional HTFs. This, in turn, can improve efficiencies and reduce the costs of CSP plants [186-188]. However, many authors are concerned with using nanofluid in CSP systems and performed investigations on the achievable enhancement in the performance of these systems [189-198].

\subsection{Automobiles Applications}

In recent years, the energy crisis and fuel economy created a competition between automobiles manufacturers. According to this, designers have to improve the aerodynamic designs of vehicles in order to reduce the amount of energy required to overcome the drag force. Unfortunately, they face the fact that more than $50 \%$ of the total vehicle energy output is lost in overcoming the aerodynamic drag. The large radiator position in the vehicle front is partly responsible for this fact [199]. Therefore, it is required to replace poor cooling medium, such as EG-water mixture, with nanofluids to remove heat from relatively smaller size [200,201].

Many researchers have been attracted to investigate, either experimentally or numerically, the use of nanofluids as engine coolant [202-208]. They reported excellent enhancements in the thermal properties of nanofluids, such as EG-based nanofluids, compared to conventional coolants, e.g. 50/50 mixture of EG and water. In addition, some authors indicated that the frontal area of the radiator can be reduced up to $10 \%$ due to the use of nanofluid coolants. This in turn can lead to reduce aerodynamic drag and save fuel up to 5\% [204]. Engine cooling is not only the application of using nanofluids in automobiles, but also they can be used to cool other moving parts in an automobile. Tzeng et al. [209] dispersed nanoparticles into engine transmission oil. They reported that the thermal performance of nanofluids has a clear advantage as they produced the lowest transmission temperatures at both low and high speeds.

\subsection{Electronic Cooling Applications}

Heat transfer at medium and low temperatures is also affected by the improvements raised by nanofluids. Nanofluids are used as the working fluid in heat pipes and thermosyphons, which can be utilized for compact device cooling, e.g. electronic devices. Some researchers investigated the use of nanofluids in heat pipes [210-217], while others studied the effect of using nanofluids on the performance of thermosyphons [218-226]. They observed obvious enhancements in thermosyphons performance, as a result of the reduction of thermosyphons thermal resistance due to the use of nanofluids. Other researchers investigated the use of nanofluids in electronic devices of cooling systems [227,228]. They also reported higher cooling performance in their coolers.

\subsection{Medical Applications}

Recently, nanofluids contributed in a wide range of applications in medical applications and biomedical industry [229]. Nanofluids have been used in nano-medicine applications as iron based nanoparticles can be used as nanodrug delivery vehicles [230-237]. Nanofluids can be also used in cancer therapeutics. They can be utilized in cancer imaging and drug delivery, by using magnetic nanofluids which guide the particles up the bloodstream to a tumor with magnets. In addition, they can be used to kill cancerous cells without affecting the nearby healthy cells by producing higher temperatures around tumors [238-241]. On the other hand, nanofluids can also be used in Cryosurgery, which is a procedure that uses freezing to destroy undesired tissues. This procedure can be regarded as a novel method of cancer treatment [241,242]. In addition, nanofluids can be used to avoid risk of organ damage by cooling around the surgical region in surgery operations [243].

\subsection{Other Applications}

Many other fields were invaded by nanofluids. They can be used in detergency. Nanofluids differ from conventional simple liquids as they have different behavior of spreading and adhesion on solid surfaces [244-247]. According to this fact, nanofluids arise as excellent candidates in lubrication, processes of soil remediation, oil recovery and detergency. Nanofluids are also applied in some military applications. In such applications, high heat flux cooling fluids are required in order to remove a large amount of heat from both military mechanical and electrical devices, e.g. submarines and high power laser [243].

\section{Conclusions}

The present work reviewed recent research progress achieved in enhancing thermal conductivity using nanofluids. In addition, some practical applications that used the improvements resulting from the use of nanofluids were presented including solar thermal applications, automotives, electronic cooling, medical, detergency and military applications. According to this contribution, it can be found that the main parameters affecting heat transfer properties of the base fluid are nanoparticles concentration, size, shape, thermal conductivity, base fluid type, nanofluid temperature and preparation technique. The key parameter which had the most significant effect was nanoparticle concentration. It was found in most literature that it has a direct proportional relationship with thermal conductivity enhancement. However, this relation was found to be limited and extra particle loadings dramatically affect such enhancement. For particles size, it was quite agreed that is the relation was inversely proportional with thermal conductivity improvement for spherical particles, while large size cylindrical-shaped particles can enhance effective conductivity than small spherical ones. The particle shape was also found to be a critical parameter. Nanotubes were found to increase thermal conductivity compared to spherical particles, while fullerenes showed lower enhancement. Selecting particles with higher thermal conductivity, including using metallic particles, was recommended by many authors to increase the nanofluid 
thermal conductivity. In addition, it was found by some researchers that the thermal conductivity improvement was found to be inversely proportional to the base fluid thermal conductivity, while other authors reported an opposite finding. Moreover, using mixed base fluids has been emerged as a new research trend. However, mixing fluids was found to be investigated intensively, as small difference in mixing ratio affects thermal conductivity significantly. Nanofluid temperature effect was found to be much weaker than volumetric concentration, but it also found to increase thermal conductivity by raising the fluid temperature. Agglomeration leads to losing the advantage of using nanofluids. Therefore, using appropriate surfactants and sonication are required to improve nanoparticles dispersion

\section{REFERENCES}

[1] Mangrulkar CK, Kriplani VM. Nanofluid Heat TransferA Review. Int J Eng Technol 2013;3:136-42.

[2] Aberoumand S, Aberoumand H, Javaherdeh K. Improve heat transfer by using nanofluids: A review. Am J Adv Sci Res 2013;1:375-86.

[3] Maxwell JC. A Treatise on Electricity and Magnetism. Oxford : Clarendon Press; 1873.

[4] Adikwu MU. Biopolymers In Drug Delivery: Recent Advances and Challenges. Bentham Science Publishers Ltd; 2009. doi:10.2174/97816080507891090101.

[5] Kleinstreuer C, Feng Y. Experimental and theoretical studies of nanofluid thermal conductivity enhancement: A review. Nanoscale Res Lett 2011;6:113.

[6] Wang X-Q Mujumdar AS. Heat transfer characteristics of nanofluids: A review. Int J Therm Sci 2007;46:1-19.

[7] Keblinski P, Prasher R, Eapen J. Thermal conductance of nanofluids: Is the controversy over? J Nanoparticle Res 2008;10:1089-97.

[8] Wen D, Lin G, Vafaei S, Zhang K. Review of nanofluids for heat transfer applications. Particuology 2009;7:141-50.

[9] Keblinski P. Thermal Conductivity of Nanofluids. Therm. Nanosyst. Nanomater., Springer; 2009, p. 21321.

[10] Godson L, Raja B, Lal DM, Wongwises S. Enhancement of heat transfer using nanofluids-An overview. Renew Sustain Energy Rev 2010;14:692-641.

[11] Özerinç S, Kakaç S, Yazıcıoğlu AG. Enhanced thermal conductivity of nanofluids: a state-of-the-art review. Microfluid Nanofluidics 2010;8:145-70.

[12] Nkurikiyimfura I, Wang Y, Pan Z. Heat transfer enhancement by magnetic nanofluids-A review. Renew Sustain Energy Rev 2013;21:548-61.

[13] Charde AA, Wele D V, Thorat PV. Synthesis and Characterization of Water Based Silver Nanofluids. Natl. Conf. Adv. Technol. Comput. Netw., Amravati, India: 2015, p. 344-6.

[14] Upman KK, Srivastava A. Study on Parameters of Thermal Conductivity Enhancement in Oxide Nanofluids. Int J Eng Manag Sci 2014;1:10-20.

[15] Puliti G, Paolucci S, Sen M. Nanofluids and Their Properties. Appl Mech Rev 2012;64:030803. doi:10.1115/1.4005492. behavior. It was found that thermal conductivity increased with increasing the $\mathrm{pH}$ value up to a certain limit (8-9.5), while turns to be inversely proportional beyond this point. In addition, it was recommended to apply a moderate sonicating time, as very low time keeps nanoparticles agglomerated, while intensive sonication breaks down the agglomerates size leading to quick suspensions precipitation.

\section{Acknowledgment}

I have to express out appreciation to Berge 0. Djebedjian for his scientific guidance and valuable comments on the earlier version of the manuscript.

[16] Sadeghinezhad E, Mehrali M, Saidur R, Mehrali M, Tahan Latibari S, Akhiani AR, et al. A comprehensive review on graphene nanofluids: Recent research, development and applications. Energy Convers Manag 2016;111:466-87. doi:10.1016/j.enconman.2016.01.004.

[17] Mehrali M, Sadeghinezhad E, Latibari ST, Kazi SN, Mehrali M, Zubir MNBM, et al. Investigation of thermal conductivity and rheological properties of nanofluids containing graphene nanoplatelets. Nanoscale Res Lett 2014;9:1-12. doi:10.1186/1556-276X-9-15.

[18] Sadeghinezhad E, Mehrali M, Latibari ST, Mehrali M, Kazi SN, Oon CS, et al. Experimental Investigation of Convective Heat Transfer Using Graphene Nanoplatelet Based Nanofluids under Turbulent Flow Conditions. Ind Eng Chem Res 2014;53:12455-65. doi:10.1021/ie501947u.

[19] Mohd Zubir MN, Badarudin A, Kazi SN, Huang NM, Misran M, Sadeghinezhad E, et al. Highly dispersed reduced graphene oxide and its hybrid complexes as effective additives for improving thermophysical property of heat transfer fluid. Int J Heat Mass Transf 2015;87:284-94.

doi:10.1016/j.ijheatmasstransfer.2015.04.017.

[20] Sharma G. Thermal conductivity and viscosity of $\mathrm{Al}_{2} \mathrm{O}_{3}$ nanofluid based on car. Thapar University, 2013. doi:10.1088/0022-3727/43/31/315501.

[21] Das SK, Choi SU, Yu W, Pradeep T. Nanofluids: Science and Technology. Wiley; 2008.

[22] Masuda H, Ebata A, Teramae K, Hishinuma N. Alteration of thermal conductivity and viscosity of liquid by dispersing ultra fine particles. Netsu Bussei 1993;7:227-33.

[23] Xie H, Wang J, Xi T, Liu Y. Thermal conductivity of suspensions containing nanosized $\mathrm{SiC}$ particles. Int J Thermophys 2002;23:571-80.

[24] Assael MJ, Metaxa IN, Arvanitidis J, Christofilos D, Lioutas C. Thermal Conductivity Enhancement in Aqueous Suspensions of Carbon Multi-Walled and Double-Walled Nanotubes in the Presence of Two Different Dispersants. Int J Thermophys 2005;26:64764. doi:10.1007/s10765-005-5569-3.

[25] Hong TT-K, Yang HH-S, Choi CJ. Study of the enhanced thermal conductivity of Fe nanofluids. J Appl Phys 2005;97:064311. doi:10.1063/1.1861145.

[26] Liu M-S, Lin MC-C, Huang I-T, Wang C-C. Enhancement of thermal conductivity with carbon nanotube for 
nanofluids. Int Commun Heat Mass Transf 2005;32:1202-10.

[27] Murshed SMS, Leong KC, Yang C. Enhanced thermal conductivity of $\mathrm{TiO}_{2}$ water based nanofluids. Int J Therm Sci 2005;44:367-73.

[28] Ding Y, Alias H, Wen D, Williams RA. Heat transfer of aqueous suspensions of carbon nanotubes (CNT nanofluids). Int J Heat Mass Transf 2006;49:240-50.

[29] Kim SH, Choi SR, Kim D. Thermal Conductivity of Metal-Oxide Nanofluids: Particle Size Dependence and Effect of Laser Irradiation. J Heat Transfer 2007;129:298-307. doi:10.1115/1.2427071.

[30] Timofeeva E V., Gavrilov AN, McCloskey JM, Tolmachev Y V., Sprunt S, Lopatina LM, et al. Thermal conductivity and particle agglomeration in alumina nanofluids: Experiment and theory. Phys Rev E 2007;76:061203.

[31] Yoo D-H, Hong KS, Yang H-S. Study of thermal conductivity of nanofluids for the application of heat transfer fluids. Thermochim Acta 2007;455:66-9.

[32] Zhang X, Gu H, Fujii M. Effective thermal conductivity and thermal diffusivity of nanofluids containing spherical and cylindrical nanoparticles. Exp Therm Fluid Sci 2007;31:593-9.

[33] Zhu HT, Zhang CY, Tang YM, Wang JX. Novel synthesis and thermal conductivity of $\mathrm{CuO}$ nanofluid. J Phys Chem C 2007;111:1646-50.

[34] Murshed SMS, Leong KC, Yang C. Investigations of thermal conductivity and viscosity of nanofluids. Int J Therm Sci 2008;47:560-8.

[35] Beck MP, Yuan Y, Warrier P, Teja AS. The effect of particle size on the thermal conductivity of alumina nanofluids. J Nanoparticle Res 2009;11:1129-36.

[36] Buongiorno J, Venerus DC, Prabhat N, McKrell T, Townsend J, Christianson R, et al. A benchmark study on the thermal conductivity of nanofluids. J Appl Phys 2009;106:094312. doi:10.1063/1.3245330.

[37] Teng T-P, Hung Y-H, Teng T-C, Mo H-E, Hsu H-G. The effect of alumina/water nanofluid particle size on thermal conductivity. Appl Therm Eng 2010;30:22138.

[38] Czarnetzki W, Roetzel W. Temperature oscillation techniques for simultaneous measurement of thermal diffusivity and conductivity. Int J Thermophys 1995;16:413-22.

[39] Das SK, Putra N, Thiesen P, Roetzel W. Temperature Dependence of Thermal Conductivity Enhancement for Nanofluids. J Heat Transfer 2003;125:567-74. doi:10.1115/1.1561080.

[40] Oh D-W, Jain A, Eaton JK, Goodson KE, Lee JS. Thermal conductivity measurement and sedimentation detection of aluminum oxide nanofluids by using the $3 \omega$ method. Int J Heat Fluid Flow 2008;29:1456-61.

[41] Choi TY, Maneshian MH, Kang B, Chang WS, Han CS, Poulikakos D. Measurement of the thermal conductivity of a water-based single-wall carbon nanotube colloidal suspension with a modified 3- $\omega$ method. Nanotechnology 2009;20:315706.

[42] Paul G, Chopkar M, Manna I, Das PK. Techniques for measuring the thermal conductivity of nanofluids: A review. Renew Sustain Energy Rev 2010;14:1913-24.

[43] Wang X, Xu X, S. Choi SU. Thermal Conductivity of
Nanoparticle - Fluid Mixture. J Thermophys Heat Transf 1999;13:474-80. doi:10.2514/2.6486.

[44] Putnam SA, Cahill DG, Braun P V., Ge Z, Shimmin RG. Thermal conductivity of nanoparticle suspensions. J Appl Phys 2006;99:084308. doi:10.1063/1.2189933.

[45] Ju YS, Kim J, Hung M-T. Experimental study of heat conduction in aqueous suspensions of aluminum oxide nanoparticles. J Heat Transfer 2008;130:092403.

[46] Davis WR. Hot-wire method for the measurement of the thermal conductivity of refractory materials. In: Maglić KD, Cezairliyan A, Peletsky VE, editors. Compend. Thermophys. Prop. Meas. Methods, Vol. 1, New York, London: Plenum Press; 1984, p. 161.

[47] Feng Y. A new thermal conductivity model for nanofluids with convection heat transfer application. North Carolina State University, Raleigh, NC, USA, 2010.

[48] Vadasz P. Rendering the transient hot wire experimental method for thermal conductivity estimation to two-phase systems-theoretical leading order results. J Heat Transfer 2010;132:1-7.

[49] Chiesa M, Simonsen A. The importance of suspension stability for hot-wire measurements of thermal conductivity of colloidal suspensions. 16th Australas. Fluid Mech. Conf., Gold Coast, Australia: 2010.

[50] Roetzel W, Prinzen S, Xuan Y. Measurement of thermal diffusivity using temperature oscillations thermal conductivity. In: Cremers CJ, Fine HA, editors. Therm. Conduct. Int. Conf. Proc. 21st. 1st ed., Springer US; 1990, p. 201-7.

[51] Purna C, Mishra PC, Nayak SK, Mukherjee S. Thermal conductivity of nanofluids-An extensive literature review. Int J Eng Res Technol 2013;2:734-45.

[52] Paul TC, Morshed AKMM, Fox EB, Visser AE, Bridges NJ, Khan JA. Enhanced thermal performance of ionic liquid- $\mathrm{Al}_{2} \mathrm{O}_{3}$ nanofluid as heat transfer fluid for solar collector. Proc. ASME 2013 7th Int. Conf. Energy Sustain., Minneapolis, MN, USA: ASME; 2013, p. 1-7.

[53] Zhang X, Gu H, Fujii M. Experimental Study on the Effective Thermal Conductivity and Thermal Diffusivity of Nanofluids. Int J Thermophys 2006;27:569-80. doi:10.1007/s10765-006-0054-1.

[54] Woodfield PL, Fukai J, Fujii M, Takata Y, Shinzato K. A Two-Dimensional Analytical Solution for the Transient Short-Hot-Wire Method. Int J Thermophys 2008;29:1278-98. doi:10.1007/s10765-008-0469-y.

[55] Mintsa HA, Roy G, Nguyen CT, Doucet D. New temperature dependent thermal conductivity data for water-based nanofluids. Int J Therm Sci 2009;48:36371. doi:10.1016/j.ijthermalsci.2008.03.009.

[56] Ali FM, Yunus WMM, Moksin MM, Talib ZA. The effect of volume fraction concentration on the thermal conductivity and thermal diffusivity of nanofluids: numerical and experimental. Rev Sci Instrum 2010;81:074901. doi:10.1063/1.3458011.

[57] Rusconi R, Rodari E, Piazza R. Optical measurements of the thermal properties of nanofluids. Appl Phys Lett 2006;89:261916. doi:10.1063/1.2425015.

[58] Venerus DC, Kabadi MS, Lee S, Perez-Luna V. Study of thermal transport in nanoparticle suspensions using forced Rayleigh scattering. J Appl Phys 
2006;100:094310. doi:10.1063/1.2360378.

[59] Schmidt AJ, Chiesa M, Torchinsky DH, Johnson JA, Nelson KA, Chen G. Thermal conductivity of nanoparticle suspensions in insulating media measured with a transient optical grating and a hotwire. J Appl Phys 2008;103:083529. doi:10.1063/1.2908887.

[60] Kolade B, Goodson KE, Eaton JK. Convective Performance of Nanofluids in a Laminar Thermally Developing Tube Flow. J Heat Transfer 2009;131:052402.

[61] Bazan J. Thermal conductivity of poly-aelpha-olefin (PAO)-based nanofluids. University of Dayton, Dayton, OH, USA, 2010.

[62] Rusconi R, Isa L, Piazza R. Thermal-lensing measurement of particle thermophoresis in aqueous dispersions. J Opt Soc Am B 2004;21:605-16.

[63] Urbach W, Hervet H, Rondelez F. Thermal Diffusivity Measurements in Nematic and Smectic Phases by Forced Rayleigh Light Scattering. Mol Cryst Liq Cryst 1978;46:209-21. doi:10.1080/00268947808083724.

[64] Benedek GB. Optical Mixing Spectroscopy with Applications to Problems in Physics, Chemistry, Biology and Engineering. Polariz. Matter Radiat. (The Jubil. Vol. Honor Alfred Kastler), Paris: Presse Universitaires de France; 1969.

[65] Venerus DC, Schieber JD, Iddir H, Guzman JD, Broerman AW. Measurement of thermal diffusivity in polymer melts using forced Rayleigh light scattering. J Polym Sci Part B Polym Phys 1999;37:1069-78.

[66] Putnam SA, Cahill DG. Micron-scale apparatus for measurements of thermodiffusion in liquids. Rev Sci Instrum 2004;75:2368-72. doi:10.1063/1.1765761.

[67] Shaikh S, Lafdi K, Ponnappan R. Thermal conductivity improvement in carbon nanoparticle doped PAO oil: An experimental study. J Appl Phys 2007;101:064302. doi:10.1063/1.2710337.

[68] Choi US, Rogers CS, Mills DM. High-performance microchannel heat exchanger for cooling high-heatload x-ray optical elements. In: Cho D, Peterson JP, Pisano AP, Friedrich C, editors. Micromechanical Syst., New York: American Society of Mechanical Engineers (ASME); 1992.

[69] Eastman JA, Choi US, Li S, Thompson LJ, Lee S. Enhanced Thermal Conductivity through the Development of Nanofluids. Mater. Res. Soc. Proc., vol. 457, Cambridge University Press; 1997, p. 3. doi:10.1557/PROC-457-3.

[70] Pak BC, Cho YIY. Hydrodynamic and Heat Transfer Study of Dispersed Fluids With Submicron Metallic Oxide Particles. Exp Heat Transf 1998;11:151-70. doi:10.1080/08916159808946559.

[71] Lee SS, Choi SUS, Li S, Eastman JA. Measuring thermal conductivity of fluids containing oxide nanoparticles. J Heat Transfer 1999;121:280-9. doi:10.1115/1.2825978.

[72] Xuan Y, Li Q. Heat transfer enhancement of nanofluids. Int J Heat Fluid Flow 2000;21:58-64.

[73] Eastman JA, Choi SUS, Li S, Yu W, Thompson LJ. Anomalously increased effective thermal conductivities of ethylene glycol-based nanofluids containing copper nanoparticles. Appl Phys Lett 2001;78:718-20. doi:10.1063/1.1341218.

[74] Choi SUS, Zhang ZG, Yu W, Lockwood FE, Grulke EA. Anomalous thermal conductivity enhancement in nanotube suspensions. Appl Phys Lett 2001;79:22524. doi:10.1063/1.1408272.

[75] Wang Y, Fisher TS, Davidson JL, Jiang L. Thermal conductivity of nanoparticle suspensions. Proc. 8th AIAA/ASME Jt. Thermophys. Heat Transf. Conf., St. Louis, MO: 2002, p. 1-6. doi:10.2514/6.2002-3345.

[76] Xie H, Wang J, Xi T, Liu Y, Ai F, Wu Q. Thermal conductivity enhancement of suspensions containing nanosized alumina particles. J Appl Phys 2002;91:4568-72. doi:10.1063/1.1454184.

[77] Xie H, Lee H, Youn W, Choi M. Nanofluids containing multiwalled carbon nanotubes and their enhanced thermal conductivities. J Appl Phys 2003;94:4967-71. doi:10.1063/1.1613374.

[78] Patel HE, Das SK, Sundararajan T, Sreekumaran Nair A, George B, Pradeep T. Thermal conductivities of naked and monolayer protected metal nanoparticle based nanofluids: Manifestation of anomalous enhancement and chemical effects. Appl Phys Lett 2003;83:2931-3. doi:10.1063/1.1602578.

[79] Wen D, Ding Y. Effective Thermal Conductivity of Aqueous Suspensions of Carbon Nanotubes (Carbon Nanotube Nanofluids). J Thermophys Heat Transf 2004;18:481-5. doi:10.2514/1.9934.

[80] Chon CH, Kihm KD, Lee SP, Choi SUS. Empirical correlation finding the role of temperature and particle size for nanofluid $\left(\mathrm{Al}_{2} \mathrm{O}_{3}\right)$ thermal conductivity enhancement. Appl Phys Lett 2005;87:153107. doi:10.1063/1.2093936.

[81] Prasher RS, Bhattacharya P, Phelan PE. Effect of Aggregation Kinetics on the Thermal Conductivity of Nanoscale Colloidal Solutions (Nanofluids). Nanoletters 2006;6:1529-34.

[82] Chopkar M, Das PK, Manna I. Synthesis and characterization of nanofluid for advanced heat transfer applications. Scr Mater 2006;55:549-52. doi:10.1016/j.scriptamat.2006.05.030.

[83] Ceylan A, Jastrzembski K, Shah SI. Enhanced solubility Ag-Cu nanoparticles and their thermal transport properties. Metall Mater Trans A 2006;37:2033-8. doi:10.1007/BF02586123.

[84] Hwang YJ, Ahn YC, Shin HS, Lee CG, Kim GT, Park HS, et al. Investigation on characteristics of thermal conductivity enhancement of nanofluids. Curr Appl Phys 2006;6:1068-71. doi:10.1016/j.cap.2005.07.021.

[85] Li CH, Peterson GP. Experimental investigation of temperature and volume fraction variations on the effective thermal conductivity of nanoparticle suspensions (nanofluids). J Appl Phys 2006;99:084314. doi:10.1063/1.2191571.

[86] Wen D, Ding Y. Natural convective heat transfer of suspensions of titanium dioxide nanoparticles (nanofluids). IEEE Trans Nanotechnol 2006;5:220-7. doi:10.1109/tnano.2006.874045.

[87] He Y, Jin Y, Chen H, Ding Y, Cang D, Lu H. Heat transfer and flow behaviour of aqueous suspensions of $\mathrm{TiO}_{2}$ nanoparticles (nanofluids) flowing upward through a 
vertical pipe. Int J Heat Mass Transf 2007;50:2272-81. doi:10.1016/j.ijheatmasstransfer.2006.10.024.

[88] Li CH, Peterson GP. The effect of particle size on the effective thermal conductivity of Al203-water nanofluids. J Appl Phys 2007;101:044312. doi:10.1063/1.2436472.

[89] Hwang Y, Lee JK, Lee CH, Jung Y, Cheong SI, Lee CG, et al. Stability and thermal conductivity characteristics of nanofluids. Thermochim Acta 2007;455. doi:10.1016/j.tca.2006.11.036.

[90] Chopkar M, Sudarshan S, Das PK, Manna I. Effect of Particle Size on Thermal Conductivity of Nanofluid. Metall Mater Trans A 2008;39:1535-42. doi:10.1007/s11661-007-9444-7.

[91] Philip J, Shima P, Raj B. Evidence for enhanced thermal conduction through percolating structures in nanofluids. Nanotechnology 2008;19:305706.

[92] Duangthongsuk W, Wongwises S. Measurement of temperature-dependent thermal conductivity and viscosity of $\mathrm{TiO}_{2}$-water nanofluids. Exp Therm Fluid Sci 2009;33:706-14. doi:10.1016/j.expthermflusci.2009.01.005.

[93] Turgut A, Tavman I, Chirtoc M, Schuchmann HP, Sauter C, Tavman S. Thermal Conductivity and Viscosity Measurements of Water-Based Ti02 Nanofluids. Int J Thermophys 2009;30:1213-26. doi:10.1007/s10765009-0594-2.

[94] Zhu D, Li X, Wang N, Wang X, Gao J, Li H. Dispersion behavior and thermal conductivity characteristics of $\mathrm{Al}_{2} \mathrm{O}_{3}-\mathrm{H}_{2} \mathrm{O}$ nanofluids. Curr Appl Phys 2009;9:131-9. doi:10.1016/j.cap.2007.12.008.

[95] Abareshi M, Goharshadi EK, Mojtaba Zebarjad S, Khandan Fadafan $H$, Youssefi A. Fabrication, characterization and measurement of thermal conductivity of $\mathrm{Fe}_{3} \mathrm{O}_{4}$ nanofluids. J Magn Magn Mater 2010;322:3895-901.

doi:10.1016/j.jmmm.2010.08.016.

[96] Beck MP, Yuan Y, Warrier P, Teja AS. The thermal conductivity of alumina nanofluids in water, ethylene glycol, and ethylene glycol + water mixtures. J Nanoparticle Res 2010;12:1469-77. doi:10.1007/s11051-009-9716-9.

[97] Yu W, Xie H, Chen L, Li Y. Enhancement of thermal conductivity of kerosene-based $\mathrm{Fe}_{3} \mathrm{O}_{4}$ nanofluids prepared via phase-transfer method. Colloids Surfaces A Physicochem Eng Asp 2010;355:109-13. doi:10.1016/j.colsurfa.2009.11.044.

[98] Lee SW, Park SD, Kang S, Bang IC, Kim JH. Investigation of viscosity and thermal conductivity of $\mathrm{SiC}$ nanofluids for heat transfer applications. Int J Heat Mass Transf 2011;54:433-8.

doi:10.1016/j.ijheatmasstransfer.2010.09.026.

[99] Harish S, Ishikawa K, Einarsson E, Aikawa S, Inoue T, Zhao $\mathrm{P}$, et al. Temperature Dependent Thermal Conductivity Increase of Aqueous Nanofluid with Single Walled Carbon Nanotube Inclusion. Mater Express 2012;2:213-23. doi:10.1166/mex.2012.1074.

[100] Harish S, Ishikawa K, Einarsson E, Aikawa S, Chiashi S, Shiomi J, et al. Enhanced thermal conductivity of ethylene glycol with single-walled carbon nanotube inclusions. Int J Heat Mass Transf 2012;55:3885-90. doi:10.1016/j.ijheatmasstransfer.2012.03.001.

[101] Khedkar RS, Sonawane SS, Wasewar KL. Influence of $\mathrm{CuO}$ nanoparticles in enhancing the thermal conductivity of water and monoethylene glycol based nanofluids. Int Commun Heat Mass Transf 2012;39:665-9.

doi:10.1016/j.icheatmasstransfer.2012.03.012.

[102] Fakoor Pakdaman M, Akhavan-Behabadi MA, Razi P. An experimental investigation on thermo-physical properties and overall performance of MWCNT/heat transfer oil nanofluid flow inside vertical helically coiled tubes. Exp Therm Fluid Sci 2012;40:103-11. doi:10.1016/j.expthermflusci.2012.02.005.

[103] Sun C, Bai B, Lu W-QQ Liu J. Shear-rate dependent effective thermal conductivity of $\mathrm{H}_{2} \mathrm{O}+\mathrm{SiO}_{2}$ nanofluids. Phys Fluids 2013;25:052002. doi:10.1063/1.4802049.

[104] Sundar LS, Farooky MH, Sarada SN, Singh MK. Experimental thermal conductivity of ethylene glycol and water mixture based low volume concentration of $\mathrm{Al}_{2} \mathrm{O}_{3}$ and $\mathrm{CuO}$ nanofluids. Int Commun Heat Mass Transf 2013;41:41-6. doi:10.1016/j.icheatmasstransfer.2012.11.004.

[105] Angayarkanni SA, Philip J. Effect of nanoparticles aggregation on thermal and electrical conductivities of nanofluids. J Nanofluids 2014;3:17-25.

[106] Cingarapu S, Singh D, Timofeeva E V., Moravek MR. Nanofluids with encapsulated tin nanoparticles for advanced heat transfer and thermal energy storage. Int J Energy Res 2014;38:51-9. doi:10.1002/er.3041.

[107] Buonomo B, Manca O, Marinelli L, Nardini S. Effect of temperature and sonication time on nanofluid thermal conductivity measurements by nano-flash method. Appl Therm Eng 2015;91:181-90. doi:10.1016/j.applthermaleng.2015.07.077.

[108] Hemmat Esfe M, Yan W-M, Akbari M, Karimipour A, Hassani M. Experimental study on thermal conductivity of DWCNT-ZnO/water-EG nanofluids. Int Commun Heat Mass Transf 2015;68:248-51. doi:10.1016/j.icheatmasstransfer.2015.09.001.

[109] Karimi A, Sadatlu MAA, Saberi B, Shariatmadar H, Ashjaee M. Experimental investigation on thermal conductivity of water based nickel ferrite nanofluids. Adv Powder Technol 2015;26:1529-36. doi:10.1016/j.apt.2015.08.015.

[110] Parametthanuwat T, Bhuwakietkumjohn N, Rittidech S, Ding Y. Experimental investigation on thermal properties of silver nanofluids. Int J Heat Fluid Flow 2015;56:80-90. doi:10.1016/j.ijheatfluidflow.2015.07.005.

[111] Usri NA, Azmi WH, Mamat R, Hamid KA, Najafi G. Thermal Conductivity Enhancement of $\mathrm{Al}_{2} \mathrm{O}_{3}$ Nanofluid in Ethylene Glycol and Water Mixture. Energy Procedia 2015;79:397-402. doi:10.1016/j.egypro.2015.11.509.

[112] Hemmat Esfe M, Afrand M, Karimipour A, Yan W-M, Sina N. An experimental study on thermal conductivity of MgO nanoparticles suspended in a binary mixture of water and ethylene glycol. Int Commun Heat Mass Transf 2015;67:173-5. doi:10.1016/j.icheatmasstransfer.2015.07.009.

[113] Li X, Zou C, Zhou L, Qi A. Experimental study on the thermo-physical properties of diathermic oil based $\mathrm{SiC}$ 
nanofluids for high temperature applications. Int J Heat Mass Transf 2016;97:631-7. doi:10.1016/j.ijheatmasstransfer.2016.02.056.

[114] Li H, Wang L, He Y, Hu Y, Zhu J, Jiang B. Experimental investigation of thermal conductivity and viscosity of ethylene glycol based $\mathrm{ZnO}$ nanofluids. Appl Therm Eng 2015;88:363-8.

doi:10.1016/j.applthermaleng.2014.10.071.

[115] Agarwal R, Verma K, Agrawal NK, Duchaniya RK, Singh R. Synthesis, characterization, thermal conductivity and sensitivity of $\mathrm{CuO}$ nanofluids. Appl Therm Eng 2016;102:1024-36. doi:10.1016/j.applthermaleng.2016.04.051.

[116] Aberoumand S, Jafarimoghaddam A, Moravej M, Aberoumand $\mathrm{H}$, Javaherdeh K. Experimental study on the rheological behavior of silver-heat transfer oil nanofluid and suggesting two empirical based correlations for thermal conductivity and viscosity of oil based nanofluids. Appl Therm Eng 2016. doi:10.1016/j.applthermaleng.2016.01.148.

[117] Khedkar RS, Shrivastava N, Sonawane SS, Wasewar KL. Experimental investigations and theoretical determination of thermal conductivity and viscosity of $\mathrm{TiO}_{2}$-ethylene glycol nanofluid. Int Commun Heat Mass Transf 2016;73:54-61. doi:10.1016/j.icheatmasstransfer.2016.02.004.

[118] Sadegh A, Kourosh J, Amin J, Hossein A. A Complete Experimental Investigation on The Rheological Behavior of Silver Nanofluid. Heat Transf Res 2016:116. doi:10.1002/htj.21212.

[119] Xing M, Yu J, Wang R. Experimental investigation and modelling on the thermal conductivity of CNTs based nanofluids. Int J Therm Sci 2016;104:404-11. doi:10.1016/j.ijthermalsci.2016.01.024.

[120] Eggersdorfer ML. Nanoparticle Agglomerates and Aggregates in Aerosols by Coagulation and Sintering. ETH Zürich, 2012.

[121] Jena SK, Mahapatra SK. Numerical modeling of interaction between surface radiation and natural convection of atmospheric aerosol in presence of transverse magnetic field. Appl Math Model 2013;37:527-39.

[122] Kaufman Y. Aerosol forcing of climate. New York: Wiley; 1994.

[123] Russell PB, Kinne SA, Bergstrom RW. Aerosol climate effects: Local radiative forcing and column closure experiments. J Geophys Res Atmos 1997;102:9397407. doi:10.1029/97JD00112.

[124] Nguyen H V, Okuyama K, Mimura T, Kousaka Y, Flagan RC, Seinfeld JH. Homogeneous and heterogeneous nucleation in a laminar flow aerosol generator. J Colloid Interface Sci 1987;119:491-504. doi:10.1016/0021-9797(87)90295-5.

[125] Muñoz-Bueno R, Hontañón E, Rucandio MI. Deposition of fine aerosols in laminar tube flow at high temperature with large gas-to-wall temperature gradients. J Aerosol Sci 2005;36:495-520. doi:10.1016/j.jaerosci.2004.11.002.

[126] Akbar MK, Rahman M, Ghiaasiaan SM. Particle transport in a small square enclosure in laminar natural convection. J Aerosol Sci 2009;40:747-61. doi:10.1016/j.jaerosci.2009.04.007.

[127] Housiadas C, Papanicolaou E, Drossinos Y. Combined heat and mass transfer in laminar flow diffusion nucleation chambers. J Aerosol Sci 2002;33:797-816. doi:10.1016/S0021-8502(01)00214-2.

[128] Hudson A. Computational Analysis to Enhance Laminar Flow Convective Heat Transfer Rate in an Enclosure Using Aerosol Nanofluids. Georgia Southern University, 2013.

[129] Bibire L, Ghenadi AS, Timofte A, Leontie L, Buzdugan M, Agop M. Possible influences of aerosols on the Schumann frequency spectrum. J Environ Prot Ecol 2011;12:1288-94.

[130] Nottale L. Fractal Space-Time And Microphysics: Towards A Theory Of Scale Relativity. World Scientific; 1993.

[131] Abdolbaqi MK, Azmi WH, Mamat R, Sharma KV, Najafi G. Experimental Investigation of Thermal Conductivity and Electrical Conductivity of BioGlycol - Water Mixture Based $\mathrm{Al}_{2} \mathrm{O}_{3}$ Nanofluid. Appl Therm Eng 2016;102:932-41. doi:10.1016/j.applthermaleng.2016.03.074.

[132] Kumar DH, Patel HE, Kumar VRR, Sundararajan T, Pradeep T, Das SK. Model for heat conduction in nanofluids. Phys Rev Lett 2004;93:144301. doi:10.1103/PhysRevLett.93.144301.

[133] Martinez A, Roberts G, Garzarella K, Lutz M, Caswell M. Interoperability of 300 watt and 150 watt xenon arc solar simulators in sun protection factor and in UVA protection factor clinical testing. Photodermatol Photoimmunol Photomed 2013;29:79-83.

[134] Kharisov BI, Kharissova OV, Ortiz-Mendez U. CRC Concise Encyclopedia of Nanotechnology. CRC Press; 2016.

[135] Shackelford JF, Alexander W. CRC Materials Science and Engineering Handbook. 3rd Ed. CRC Press; 2000.

[136] Slack GA. Thermal Conductivity of $\mathrm{MgO}, \mathrm{Al}_{2} \mathrm{O} 3$, $\mathrm{MgAl}_{2} \mathrm{O}_{4}$, and $\mathrm{Fe}_{3} \mathrm{O}_{4}$ Crystals from $3^{\circ}$ to $300^{\circ} \mathrm{K}$. Phys Rev Lett Phys Rev Rev Mod Phys 1962;126:427-41. doi:10.1103/PhysRev.126.427.

[137] Hofmeister AM. Thermal diffusivity and thermal conductivity of single-crystal $\mathrm{MgO}$ and $\mathrm{Al}_{2} \mathrm{O}_{3}$ and related compounds as a function of temperature. Phys Chem Miner 2014;41:361-71. doi:10.1007/s00269014-0655-3.

[138] Beck MP. Thermal Conductivity of Metal Oxide Nanofluids. Georgia Institute of Technology, 2008.

[139] IAEA. Thermophysical Properties of Materials For Nuclear Engineering: A Tutorial and Collection of Data. Vienna, Austria: International Atomic Energy Agency (IAEA); 2008. doi:10.1017/CB09781107415324.004.

[140] Hwang Y, Park HS, Lee JK, Jung WH. Thermal conductivity and lubrication characteristics of nanofluids. Curr Appl Phys 2006;6:e67-71. doi:10.1016/j.cap.2006.01.014.

[141] Choi SUS, Zhang ZG, Yu W, Lockwood FE, Grulke EA. Anomalous thermal conductivity enhancement in nanotube suspensions. Appl Phys Lett 2001;79:2252. doi:10.1063/1.1408272.

[142] Green D, Perry R. Perry's Chemical Engineers' Handbook. 7th Ed. McGraw-Hill Professional; 1997. 
[143] Thermal Conductivities for some common Liquids 2016. http://www.engineeringtoolbox.com/thermalconductivity-liquids-d_1260.html (accessed May 11, 2016).

[144] Putnam SA. Thermal probes of nanoparticle interfaces: Thermodiffusion and thermal conductivity of nanoparticle suspensions. University of Illinois at Urbana-Champaign, 2007.

[145] Washburn EW, West CJ, Hull C, National Academy of Sciences, International Council of Scientific Unions, National Research Council. International critical tables of numerical data, physics, chemistry and technology: Volume II. Ithaca, New York: Cornell University, Mann Library; 1927.

[146] Meyer JCA, McClintock RB, Silvestri GJ, Spencer RC. ASME Steam Tables - Thermodynamic and Transport Properties of Steam. 6th Ed. ASME; 1993.

[147] Shahsavar A, Salimpour MR, Saghafian M, Shafii MB. An experimental study on the effect of ultrasonication on thermal conductivity of ferrofluid loaded with carbon nanotubes. Thermochim Acta 2015;617:102-10. doi:10.1016/j.tca.2015.08.025.

[148] Assael MJ, Chen C-F, Metaxa I, Wakeham WA. Thermal Conductivity of Suspensions of Carbon Nanotubes in Water. Int J Thermophys n.d.;25:971-85. doi:10.1023/B:IJOT.0000038494.22494.04.

[149] Liu J, Rinzler AG, Dai H, Hafner JH, Bradley RK, Boul PJ, et al. Fullerene Pipes. Science (80- ) 1998;280:1253-6.

[150] Arthur 0, Karim MA. An investigation into the thermophysical and rheological properties of nanofluids for solar thermal applications. Renew Sustain Energy Rev 2016;55:739-55. doi:10.1016/j.rser.2015.10.065.

[151] Otanicar TP, Phelan PE, Golden JS. Optical properties of liquids for direct absorption solar thermal energy systems. Sol Energy 2009;83:969-77. doi:10.1016/j.solener.2008.12.009.

[152] Saidur R, Meng TC, Said Z, Hasanuzzaman M, Kamyar A. Evaluation of the effect of nanofluid-based absorbers on direct solar collector. Int J Heat Mass Transf 2012;55:5899-907. doi:10.1016/j.ijheatmasstransfer.2012.05.087.

[153] He Q Wang S, Zeng S, Zheng Z. Experimental investigation on photothermal properties of nanofluids for direct absorption solar thermal energy systems. Energy Convers Manag 2013;73:150-7. doi:10.1016/j.enconman.2013.04.019.

[154] Lee S-H, Jang SP. Extinction coefficient of aqueous nanofluids containing multi-walled carbon nanotubes. Int J Heat Mass Transf 2013;67:930-5. doi:10.1016/j.ijheatmasstransfer.2013.08.094.

[155] Sajid MH, Said Z, Saidur R, Adikan FRM, Sabri MFM, Rahim NA. A time variant investigation on optical properties of water based $\mathrm{Al}_{2} \mathrm{O}_{3}$ nanofluid. Int Commun Heat Mass Transf 2014;50:108-16. doi:10.1016/j.icheatmasstransfer.2013.10.006.

[156] Leong KY, Ong HC, Amer NH, Norazrina MJ, Risby MS, $\mathrm{Ku}$ Ahmad KZ. An overview on current application of nanofluids in solar thermal collector and its challenges. Renew Sustain Energy Rev 2016;53:1092105. doi:10.1016/j.rser.2015.09.060.
[157] Tyagi H, Phelan PE, Prasher R. Predicted efficiency of a low-temperature nanofluid-based direct absorption solar collector. J Sol Energy Eng 2009;131:1-26.

[158] Otanicar TP, Phelan PE, Prasher RS, Rosengarten G, Taylor RA. Nanofluid-based direct absorption solar collector. J Renew Sustain Energy 2010;2:033102. doi:10.1063/1.3429737.

[159] Lu L, Liu ZH, Xiao HS. Thermal performance of an open thermosyphon using nanofluids for high-temperature evacuated tubular solar collectors. Part 1: Indoor experiment. Sol Energy 2011;85:379-87. doi:10.1016/j.solener.2010.11.008.

[160] Yousefi T, Veysi F, Shojaeizadeh E, Zinadini S. An experimental investigation on the effect of $\mathrm{Al}_{2} \mathrm{O}_{3}-\mathrm{H}_{2} \mathrm{O}$ nanofluid on the efficiency of flat-plate solar collectors. Renew Energy 2012;39:293-8. doi:10.1016/j.renene.2014.06.003.

[161] Yousefi T, Veysi F, Shojaeizadeh E, Zinadini S. An experimental investigation on the effect of MWCNT$\mathrm{H}_{2} \mathrm{O}$ nanofluid on the efficiency of flat-plate solar collectors. Renew Energy 2012;39:207-12. doi:10.1016/j.renene.2014.06.003.

[162] Yousefi T, Shojaeizadeh E, Veysi F, Zinadini S. An experimental investigation on the effect of $\mathrm{pH}$ variation of MWCNT- $\mathrm{H}_{2} \mathrm{O}$ nanofluid on the efficiency of a flat-plate solar collector. Sol Energy 2012;86:7719. doi:10.1016/j.solener.2011.12.003.

[163] Chougule SS, Pise AT, Madane PA. Performance of nanofluid-charged solar water heater by solar tracking system. IEEE-International Conf. Adv. Eng. Sci. Manag. ICAESM-2012, 2012, p. 247-53.

[164] Liu ZH, Hu RL, Lu L, Zhao F, Xiao HS. Thermal performance of an open thermosyphon using nanofluid for evacuated tubular high temperature air solar collector. Energy Convers Manag 2013;73:13543. doi:10.1016/j.enconman.2013.04.010.

[165] Said Z, Sajid MH, Alim MA, Saidur R, Rahim NA. Experimental investigation of the thermophysical properties of $\mathrm{AL}_{2} \mathrm{O}_{3}$-nanofluid and its effect on a flat plate solar collector. Int Commun Heat Mass Transf 2013;48:99-107. doi:10.1016/j.icheatmasstransfer.2013.09.005.

[166] Tiwari AK, Ghosh P, Sarkar J. Solar water heating using nanofluids - A comprehensive overview and environmental impact analysis. Int J Emerg Technol Adv Eng 2013;3:221-4.

[167] Al-Shamani AN, Yazdi MH, Alghoul MA, Abed AM, Ruslan $\mathrm{MH}$, Mat $\mathrm{S}$, et al. Nanofluids for improved efficiency in cooling solar collectors - A review. Renew Sustain Energy Rev 2014;38:348-67. doi:10.1016/j.rser.2014.05.041.

[168] Hordy N, Rabulloud D, Meunier J, Coulombe S. High temperature and long-term stability of carbon nanotube nanofluids for direct adsorption solar thermal collectors. Sol Energy 2014;105:82-90.

[169] Luo Z, Wang C, Wei W, Xiao G, Ni M. Performance improvement of a nanofluid solar collector based on direct absorption collection (DAC) concepts. Int J Heat Mass Transf 2014;75:262-71. doi:10.1016/j.ijheatmasstransfer.2014.03.072.

[170] Mahian O, Kianifar A, Sahin AZ, Wongwises S. 
Performance analysis of a minichannel-based solar collector using different nanofluids. Energy Convers Manag 2014;88:129-38. doi:10.1016/j.enconman.2014.08.021.

[171] Said Z, Saidur R, Hepbasli A, Rahim NA. New thermophysical properties of water based $\mathrm{TiO}_{2}$ nanofluid - The hysteresis phenomenon revisited. Int Commun Heat Mass Transf 2014;58:85-95.

[172] Hossain MS, Said Z, Saidur R, Sabri MFM. Applicability of alumina nanofluid in direct absorption solar collectors. Appl Mech Mater 2015;699:366-71.

[173] Lazarus G. Nanofluid heat transfer and applications. J Therm Eng 2015;1:113. doi:10.18186/jte.93344.

[174] Goudarzi K, Nejati F, Shojaeizadeh E, Asadi Yousef-abad SK. Experimental study on the effect of $\mathrm{pH}$ variation of nanofluids on the thermal efficiency of a solar collector with helical tube. Exp Therm Fluid Sci 2015;60:20-7. doi:10.1016/j.expthermflusci.2014.07.015.

[175] Lee S-H, Jang SP. Efficiency of a volumetric receiver using aqueous suspensions of multi-walled carbon nanotubes for absorbing solar thermal energy. Int J Heat Mass Transf 2015;80:58-71. doi:10.1016/j.ijheatmasstransfer.2014.08.091.

[176] Moradi A, Sani E, Simonetti M, Francini F, Chiavazzo E, Asinari P. Carbon-nanohorn based nanofluids for a direct absorption solar collector for civil application. J Nanosci Nanotechnol 2015;15:3488-95.

[177] Tilaki RM, Iraji zad A, Mahdavi SM. Size, composition and optical properties of copper nanoparticles prepared by laser ablation in liquids. Appl Phys A 2007;88:415-9. doi:10.1007/s00339-007-4000-2.

[178] Ortega MA, Rodriguez L, Castillo J, Fernández A, Echevarria L, Wetter NU, et al. Thermo-optical Properties of Nanofluids. AIP Conf. Proc., vol. 992, AIP; 2008, p. 1172-6. doi:10.1063/1.2926813.

[179] Mercatelli L, Sani E, Fontani D, Zaccanti G, Martelli F, Ninni P Di. Scattering and absorption properties of carbon nanohorn-based nanofluids for solar energy applications. J Eur Opt Soc - Rapid Publ 2011;6:11025.

[180] Taylor RA, Phelan PE, Otanicar TP, Adrian R, Prasher R. Nanofluid optical property characterization: towards efficient direct absorption solar collectors. Nanoscale Res Lett 2011;6:1-11. doi:10.1186/1556-276X-6-225.

[181] Sani E, Mercatelli L, Barison S, Pagura C, Agresti F, Colla $\mathrm{L}$, et al. Potential of carbon nanohorn-based suspensions for solar thermal collectors. Sol Energy Mater Sol Cells 2011;95:2994-3000. doi:10.1016/j.solmat.2011.06.011.

[182] Gan Y, Qiao L. Optical Properties and RadiationEnhanced Evaporation of Nanofluid Fuels Containing Carbon-Based Nanostructures. Energy \& Fuels 2012;26:4224-30. doi:10.1021/ef300493m.

[183] Lee S, Jang SP. Extinction coefficient of aqueous nanofluids containing multi-walled carbon nanotubes. Int J Heat Mass Transf 2013;67:930-5.

[184] Sajid Hossain M, Saidur R, Mohd Sabri MF, Said Z, Hassani S. Spotlight on available optical properties and models of nanofluids: A review. Renew Sustain Energy Rev 2015;43:750-62. doi:10.1016/j.rser.2014.11.010.

[185] Sani E, Ninni P Di, Colla L, Barison S, Barison S, Agresti F. Optical properties of mixed nanofluids containing carbon nanohorns and silver nanoparticles for solar energy applications. J Nanosci Nanotechnol 2015;15:3568-73.

[186] Dincer I. Evaluation and selection of energy storage systems for solar thermal applications. Int J Energy Res 1999;23:1017-28.

[187] Dincer I. Thermal energy storage systems as a key technology in energy conservation. Int J Energy Res 2002;26:567-88.

[188] Starace AK, Gomez JC, Wang J, Pradhan S, Glatzmaier GC. Nanofluid heat capacities. J Appl Phys 2011;110:124323. doi:10.1063/1.3672685.

[189] Shin D, Jo B, Kwak H eun, Banerjee D. Investigation of high temperature nanofluids for solar thermal power conversion and storage applications. 2010 14th Int. Heat Transf. Conf., Washington, DC, USA: 2010.

[190] Kwak H, Shin D, Banerjee D. Enhanced Sensible Heat Capacity of Molten Salt and Conventional Heat Transfer Fluid Based Nanofluid for Solar Thermal Energy Storage Application. ASME 2010 4th Int. Conf. Energy Sustain., Phoenix, Arizona, USA: ASME; 2010, p. 735-9. doi:10.1115/ES2010-90295.

[191] Bridges NJ, Visser AE, Fox EB. Potential of Nanoparticle-Enhanced Ionic Liquids (NEILs) as Advanced Heat-Transfer Fluids. Energy \& Fuels 2011;25:4862-4. doi:10.1021/ef2012084.

[192] Shin D, Banerjee D. Experimental investigation of molten salt nanofluid for solar thermal energy application. ASME/JSME 2011 8th Therm. Eng. Jt. Conf., Honolulu, Hawaii, USA: ASME; 2011, p. T30024T30024 - 6. doi:10.1115/AJTEC2011-44375.

[193] Taylor RA, Phelan PE, Otanicar TP, Walker CA, Nguyen $\mathrm{M}$, Trimble S, et al. Applicability of nanofluids in high flux solar collectors. J Renew Sustain Energy 2011;3:023104. doi:10.1063/1.3571565.

[194] Khullar V, Tyagi H. A study on environmental impact of nanofluid-based concentrating solar water heating system. Int J Environ Stud 2012;69:220-32. doi:10.1080/00207233.2012.663227.

[195] Lenert A, Wang EN. Optimization of nanofluid volumetric receivers for solar thermal energy conversion. Sol Energy 2012;86:253-65. doi:10.1016/j.solener.2011.09.029.

[196] de Risi A, Milanese M, Laforgia D. Modelling and optimization of transparent parabolic trough collector based on gas-phase nanofluids. Renew Energy 2013;58:134-9. doi:10.1016/j.renene.2013.03.014.

[197] Khullar V, Tyagi H, Phelan PE, Otanicar TP, Singh H, Taylor RA. Solar Energy Harvesting Using NanofluidsBased Concentrating Solar Collector. J Nanotechnol Eng Med 2013;3:1003-12.

[198] Nasrin R, Parvin S, Alim MA. Effect of Prandtl number on free convection in a solar collector filled with nanofluid. Procedia Eng 2013;56:54-62. doi:10.1016/j.proeng.2013.03.088.

[199] Bhogare RA, Kothawale BS. A review on applications and challenges of nano-fluids as coolant in automobile radiator. Int J Sci Res Publ 2013;3:1-11.

[200] Devendiran DK, Amirtham VA. A review on preparation, characterization, properties and applications of nanofluid. Renew Sustain Energy Rev 
2016;60:21-40.

[201] Bigdeli MB, Fasano M, Cardellini A, Chiavazzo E, Asinari P. A review on the heat and mass transfer phenomena in nanofluid coolants with special focus on automotive applications. Renew Sustain Energy Rev 2016;60:1615-33. doi:10.1016/j.rser.2016.03.027.

[202] Lee S, Choi SUS. Application of metallic nanoparticle suspensions in advanced cooling systems. Int. Mech. Eng. Conf. Sess. Appl. Met. Mater. Adv. Eng. Syst., Atlanta, GA, USA: 1996.

[203] Ollivier E, Bellettre J, Tazerout M, Roy GC. Detection of knock occurrence in a gas SI engine from a heat transfer analysis. Energy Convers Manag 2006;47:879-93. doi:10.1016/j.enconman.2005.06.019.

[204] Singh D, Toutbort J, Chen G, Hull J, Smith R, Ajaya O, et al. Heavy vehicle systems optimization merit review and peer evaluation. 2006.

[205] Botha S. Synthesis and characterization of nanofluids for cooling applications. University of the Western Cape, 2007.

[206] Choi C, Yoo HS, Oh JM. Preparation and heat transfer properties of nanoparticle-in-transformer oil dispersions as advanced energy-efficient coolants. Curr Appl Phys 2008;8:710-2. doi:10.1016/j.cap.2007.04.060.

[207] Sridhara V, Gowrishankar BS, Satapathy LN. NanoFluids-A New Promising Fluid for Cooling. Trans Indian Ceram Soc 2015;68:1-17. doi:10.1080/0371750X.2009.11082156.

[208] Peyghambarzadeh SM, Hashemabadi SH, Naraki M, Vermahmoudi Y. Experimental study of overall heat transfer coefficient in the application of dilute nano fluids in the car radiator. Appl Therm Eng 2013;52:816. doi:10.1016/j.applthermaleng.2012.11.013.

[209] Tzeng S-C, Lin C-W, Huang KD. Heat transfer enhancement of nanofluids in rotary blade coupling of four-wheel-drive vehicles. Acta Mech 2005;179:11-23. doi:10.1007/s00707-005-0248-9.

[210] Tsai CY, Chien HT, Ding PP, Chan B, Luh TY, Chen PH. Effect of structural character of gold nanoparticles in nanofluid on heat pipe thermal performance. Mater Lett 2004;58:1461-5. doi:10.1016/j.matlet.2003.10.009.

[211] Wei W, Tsai S, Yang S, Kang S. Effect of Nanofluid Concentration on Heat Pipe Thermal Performance. IASME Trans 2005;2:1432-9. doi:10.1016/j.asej.2011.03.003.

[212] Kang SW, Wei WC, Tsai SH, Yang SY. Experimental investigation of silver nano-fluid on heat pipe thermal performance. Appl Therm Eng 2006;26:2377-82. doi:10.1016/j.applthermaleng.2006.02.020.

[213] Kang S-W, Wei W-C, Tsai S-H, Huang C-C. Experimental investigation of nanofluids on sintered heat pipe thermal performance. Appl Therm Eng 2009;29:9739. doi:10.1016/j.applthermaleng.2008.05.010.

[214] Naphon P, Thongkum D, Assadamongkol P. Heat pipe efficiency enhancement with refrigerantnanoparticles mixtures. Energy Convers Manag 2009;50:772-6. doi:10.1016/j.enconman.2008.09.045.

[215] Shafahi M, Bianco V, Vafai K, Manca O. An investigation of the thermal performance of cylindrical heat pipes using nanofluids. Int J Heat Mass Transf 2010;53:37683. doi:10.1016/j.ijheatmasstransfer.2009.09.019.

[216] Mousa MG. Effect of nanofluid concentration on the performance of circular heat pipe. Ain Shams Eng J 2011;2:63-9. doi:10.1016/j.asej.2011.03.003.

[217] Manimaran R, Palaniradja K, Alagumurthi N. Effect of filling ratio on thermal characteristics of circular heat pipe using nanofluid. Front Heat Pipes 2012;3:1-5.

[218] Xue HS, Fan JR, Hu YC, Hong RH, Cen KF. The interface effect of carbon nanotube suspension on the thermal performance of a two-phase closed thermosyphon. J Appl Phys 2006;100:104909. doi:10.1063/1.2357705.

[219] Khandekar S, Joshi YM, Mehta B. Thermal performance of closed two-phase thermosyphon using nanofluids. Int J Therm Sci 2008;47:659-67. doi:10.1016/j.ijthermalsci.2007.06.005.

[220] Noie SH, Heris SZ, Kahani M, Nowee SM. Heat transfer enhancement using $\mathrm{Al}_{2} \mathrm{O}_{3}$ /water nanofluid in a twophase closed thermosyphon. Int J Heat Fluid Flow 2009;30:700-5. doi:10.1016/j.ijheatfluidflow.2009.03.001.

[221] Liu Z, Yang X, Wang G, Guo G. Influence of carbon nanotube suspension on the thermal performance of a miniature thermosyphon. Int J Heat Mass Transf 2010;53:1914-20. doi:10.1016/j.ijheatmasstransfer.2009.12.065.

[222] Paramatthanuwat T, Boothaisong S, Rittidech S, Booddachan K. Heat transfer characteristics of a twophase closed thermosyphon using de ionized water mixed with silver nano. Heat Mass Transf 2009;46:281-5. doi:10.1007/s00231-009-0565-y.

[223] Parametthanuwat T, Rittidech S, Pattiya A. A correlation to predict heat-transfer rates of a twophase closed thermosyphon (TPCT) using silver nanofluid at normal operating conditions. Int J Heat Mass Transf 2010;53:4960-5. doi:10.1016/j.ijheatmasstransfer.2010.05.046.

[224] Huminic G, Huminic A, Morjan I, Dumitrache F. Experimental study of the thermal performance of thermosyphon heat pipe using iron oxide nanoparticles. Int J Heat Mass Transf 2011;54:656-61. doi:10.1016/j.ijheatmasstransfer.2010.09.005.

[225] Mousa MG. Thermal Performance of Thermosyphon Charged by Nanofluid for Cooling Electronic Component. Int J Sci Eng Res 2011;2:1-9.

[226] Shanthi R, Velraj R. Performance of two phase gravity assisted thermosyphon using nanofluids. Front Heat Pipes 2014;5:1-11.

[227] Jang SP, Choi SUS. Cooling performance of a microchannel heat sink with nanofluids. Appl Therm Eng 2006;26:2457-63. doi:10.1016/j.applthermaleng.2006.02.036.

[228] Nguyen CT, Roy G, Galanis N, Suiro S. Heat transfer enhancement by using $\mathrm{Al}_{2} \mathrm{O}_{3}$-water nanofluid in a liquid cooling system for microprocessors. Proc. 4th WSEAS Int. Conf. Heat Transf. Therm. Eng. Environ., Elounda, Greece: 2006, p. 103-8.

[229] Haile E, Shankar B. A steady MHD boundary-layer flow of water-based nanofluids over a moving permeable flat plate. Int J Math Res 2015;4:27-41. 
[230] Shawgo RS, Richards Grayson AC, Li Y, Cima MJ. BioMEMS for drug delivery. Curr Opin Solid State Mater Sci 2002;6:329-34. doi:10.1016/S13590286(02)00032-3.

[231] Kim K, Lee J-B. High aspect ratio tapered hollow metallic microneedle arrays with microfluidic interconnector. Microsyst Technol 2006;13:231-5. doi:10.1007/s00542-006-0221-0.

[232] Labhasetwar V, Leslie-Pelecky DL. Biomedical Applications of Nanotechnology. 1st Ed. WileyBlackwell; 2007.

[233] Ovsianikov A, Chichkov B, Mente P, Monteiro-Riviere NA, Doraiswamy A, Narayan RJ. Two Photon Polymerization of Polymer?Ceramic Hybrid Materials for Transdermal Drug Delivery. Int J Appl Ceram Technol 2007;4:22-9. doi:10.1111/j.17447402.2007.02115.x.

[234] Kleinstreuer C, Li J, Koo J. Microfluidics of nano-drug delivery. Int J Heat Mass Transf 2008;51:5590-7. doi:10.1016/j.ijheatmasstransfer.2008.04.043.

[235] Nikkam N. Engineering Nanofluids for Heat Transfer Applications. School of Information and Communication Technology, Royal Institute of Technology (KTH), 2014.

[236] Tripathi D, Bég OA. A study on peristaltic flow of nanofluids: Application in drug delivery systems. Int J Heat Mass Transf 2014;70:61-70. doi:10.1016/j.ijheatmasstransfer.2013.10.044.

[237] Patel AR, Vavia PR. Nanotechnology and pharmaceutical inhalation aerosols. Indian J Exp Biol 2007;45:166-74.

[238] Jordan A, Scholz R, Wust P, Fähling H. Magnetic fluid hyperthermia (MFH): Cancer treatment with $\mathrm{AC}$ magnetic field induced excitation of biocompatible superparamagnetic nanoparticles. J Magn Magn Mater 1999;201:413-9. doi:10.1016/S03048853(99)00088-8.

[239] Chiang P-C, Hung D-S, Wang J-W, Ho C-S, Yao Y-D. Engineering Water-Dispersible FePt Nanoparticles for Biomedical Applications. IEEE Trans Magn 2007;43:2445-7. doi:10.1109/TMAG.2007.894341.

[240] Bica D, Vékás L, Avdeev M V., Marinică O, Socoliuc V, Bălăsoiu M, et al. Sterically stabilized water based magnetic fluids: Synthesis, structure and properties. J Magn Magn Mater 2007;311:17-21. doi:10.1016/j.jmmm.2006.11.158.

[241] Wong K V., De Leon O. Application of nanofluids: Current and future. Adv Mech Eng 2010;2010:1-11.

[242] Vékás L, Bica D, Avdeev M V. Magnetic nanoparticles and concentrated magnetic nanofluids: Synthesis, properties and some applications. China Particuology 2007;5:43-9. doi:10.1016/j.cpart.2007.01.015.

[243] Shanthi R, Shanmuga AS, Velraj R. Heat transfer enhancement using nanofluids: An overview. Therm Sci 2012;16:423-44.

[244] Wasan DT, Nikolov AD. Spreading of nanofluids on solids. Nature 2003;423:156-9.

[245] Jeong YH, Chang WJ, Chang SH. Wettability of heated surfaces under pool boiling using surfactant solutions and nano-fluids. Int J Heat Mass Transf 2008;51:302531. doi:10.1016/j.ijheatmasstransfer.2007.09.023.
[246] Murshed SMS, Tan S hwa, Nguyen N-T. Temperature dependence of interfacial properties and viscosity of nanofluids for droplet-based microfluidics. J Phys DApplied Phys 2008;41:1-5.

[247] Sefiane K, Skilling J, MacGillivray J. Contact line motion and dynamic wetting of nanofluid solutions. Adv Colloid Interface Sci 2008;138:101-20. doi:10.1016/j.cis.2007.12.003.

[248] Gargaud M, Amils R, Quintanilla JC, Cleaves HJ, Irvine WM, Pinti D, et al., editors. Encyclopedia of Astrobiology. 1st Ed. Springer-Verlag Berlin Heidelberg; 2011. 
2016-11-23

\section{Experimental studies of nanofluid}

\section{thermal conductivity enhancement and applications: A review}

Tawfik, M. M.

Elsevier

Tawfik MM, Experimental studies of nanofluid thermal conductivity enhancement and applications: A review. Renewable and Sustainable Energy Reviews, Volume 75, August 2017, pp. 1239-1253

http://dx.doi.org/10.1016/j.rser.2016.11.111

Downloaded from Cranfield Library Services E-Repository 